\title{
Advances in the Management of Pediatric Pulmonary Hypertension
}

\author{
Peter Oishi MD, Sanjeev A Datar MD PhD, and Jeffrey R Fineman MD
}

\author{
Introduction \\ Clinical Classification and Etiology \\ Pathophysiology \\ Hemodynamics and Morphology \\ Pulmonary Vascular Endothelium \\ Pulmonary Vascular Smooth Muscle \\ Genetics \\ Management Strategies and Therapeutic Options \\ Prevention and/or Treatment of Active Pulmonary Vasoconstriction \\ Support of Right-Ventricular Function \\ Treatment of Underlying Disease \\ Promotion of Regressive Remodeling of Structural Pulmonary Vascular \\ Changes \\ Lung Transplantation \\ Summary
}

Pulmonary hypertension is a rare disease in neonates, infants, and children, and is associated with substantial morbidity and mortality. An adequate understanding of the controlling pathophysiologic mechanisms is lacking. Moreover, a minority of research is focused specifically on neonatal and pediatric populations. Although therapeutic options have increased over the past several decades, they remain limited. In advanced pulmonary hypertension, progressive pulmonary vascular functional and structural changes ultimately cause increased pulmonary vascular impedance, rightventricular failure, and death. Management includes the prevention and/or treatment of active pulmonary vasoconstriction, the support of right-ventricle function, treatment of the underlying disease (if possible), and the promotion of regressive remodeling of structural pulmonary vascular changes. Most currently available therapies augment or inhibit factors, or mediators of their downstream signaling cascades, that originate in the pulmonary vascular endothelium. These pathways include nitric-oxide/cyclic guanosine monophosphate (cGMP), prostacyclin, and endothelin-1. The ability to reverse advanced structural changes remains an as yet unattained goal. This paper reviews the epidemiology, pathophysiology, current treatments, and emerging therapies related to neonatal and pediatric pulmonary hypertension. Key words: pulmonary hypertension; pediatric; neonatal; children; infants; endothelium; pulmonary vascular disease; rho kinase; ROCK. [Respir Care 2011;56(9):1314-1339. () 2011 Daedalus Enterprises] 


\section{Advances in the Management of Pediatric Pulmonary Hypertension}

\section{Introduction}

Pulmonary hypertension $(\mathrm{PH})$ is defined as a mean pulmonary artery pressure (PAP) of $\geq 25 \mathrm{~mm} \mathrm{Hg}$ at rest. This straightforward hemodynamic definition belies the diversity of conditions that can cause or contribute to the development of $\mathrm{PH}$ in neonates, infants, and children (Table 1). Unfortunately, an adequate understanding of the controlling pathophysiologic mechanisms for most forms of $\mathrm{PH}$ is lacking. Moreover, a minority of $\mathrm{PH}$ research is focused specifically on neonatal and pediatric populations, in whom outcomes depend on the etiology. Although therapeutic options have increased over the past several decades, they remain limited. In addition, clinically relevant pulmonary vascular dysfunction that precedes a substantial increase in PAP may be important in subsets of patients. Therefore, when reviewing recent advances in the management of $\mathrm{PH}$, it is useful to place the discussion within the context of an expanding appreciation of the underlying pulmonary vascular biology, since perhaps the most promising advances are just emerging.

\section{Clinical Classification and Etiology}

As evident by the evolution of clinical classification schemes over the past 40 years, $\mathrm{PH}$ is not a single entity. The initial classification endorsed by the World Health Organization (WHO) in 1973 divided PH into only 2 categories: primary and secondary. The most recent classification, which followed the 4th world symposium on $\mathrm{PH}$ in 2008, divided PH into 5 groups and 27 subgroups (see Table 1). ${ }^{1}$ The rationale for the increasing subdivisions was to group patients who are similar in terms of clinical and pathophysiologic features and response to therapy.

The prevalence of $\mathrm{PH}$ in pediatric patients is not known precisely. A recent report from the United Kingdom Pul-

The authors are affiliated with the Division of Pediatric Critical Care Medicine, University of California, San Francisco, California.

Dr Fineman presented a version of this paper at the 47th RESPIRATORY CARE Journal Conference, "Neonatal and Pediatric Respiratory Care: What Does the Future Hold?" held November 5-7, 2010, in Scottsdale, Arizona.

This research was partly supported by National Institutes of Health grants HD047349 (to Dr Oishi) and HL61284 (to Dr Fineman), and a LeDucq Foundation Transatlantic Network development grant (to Dr Fineman).

The authors have disclosed no conflicts of interest.

Correspondence: Jeffrey R Fineman MD, Division of Pediatric Critical Care Medicine, University of California, San Francisco CA 94143-1346. E-mail: jeff.fineman@ucsf.edu.

DOI: $10.4187 /$ respcare.01297 monary Hypertension Service for Children described 64 children with idiopathic PH. ${ }^{2}$ From that cohort, the incidence of idiopathic $\mathrm{PH}$ was estimated to be 0.48 cases per million children per year, with a prevalence of 2.1 cases/ million. Survival was reported to be $89 \%, 84 \%$, and $75 \%$ at 1 year, 3 years, and 5 years, respectively. Factors predicting decreased survival included WHO functional class, and failure to thrive (based on height and weight $\mathrm{z}$-score) at presentation. A French registry that captured 50 children, with a mean age of 8.9 years, between 2005 and 2006, estimated the prevalence of $\mathrm{PH}$ to be 3.7 cases/ million. ${ }^{3}$ In that cohort, $60 \%$ had idiopathic $\mathrm{PH}, 24 \%$ had $\mathrm{PH}$ associated with congenital heart disease, and $10 \%$ had familial PH. ${ }^{3}$ An earlier report from the United Kingdom Pulmonary Hypertension Service for Children, from 2001 to 2006 , described 216 children with PH. ${ }^{4}$ In that cohort, $28 \%$ of the patients had idiopathic $\mathrm{PH}$, with a mean age at presentation of 7.37 years. Of those with associated PH (72\%, mean age at presentation 7.9 years), $31 \%$ had Eisenmenger physiology, 30\% had postoperative $\mathrm{PH}, 19 \%$ had $\mathrm{PH}$ associated with lung disease, $9 \%$ had $\mathrm{PH}$ associated with miscellaneous disorders (including human immunodeficiency virus [HIV]), bone marrow transplant, and metabolic disease, $6 \%$ had connective-tissue disease, and 5\% had $\mathrm{PH}$ associated with complex un-operated or palliated congenital heart disease. ${ }^{4}$ Between 1999 and 2005, a Swiss registry enrolled patients with $\mathrm{PH}$ and identified 23 patients ages 0 to 18 years, with a mean age at diagnosis of 3 years..$^{5}$ Of those patients, $52 \%$ had $\mathrm{PH}$ associated with congenital heart disease, $35 \%$ had idiopathic $\mathrm{PH}$, and 13\% had PH associated with pulmonary diseases. Similarly, 2 relatively large series (one European, the other 2 in the United States) that enrolled pediatric PH patients for drugtreatment trials described similar PH classification distributions. ${ }^{6,7}$

In the neonatal population, persistent pulmonary hypertension of the newborn (PPHN) warrants particular attention. The incidence of PPHN is approximately 2 per 1,000 live births. ${ }^{8}$ PPHN can be a primary disorder of the fetal pulmonary circulation, or secondary to pathologic processes that cause a maladaptive transition from the fetal to the neonatal circulation, such as meconium aspiration or surfactant deficiency, or diseases that result in abnormalities of lung development, such as congenital diaphragmatic hernia. ${ }^{9}$

In addition, there is an association between pulmonary arterial hypertension $(\mathrm{PAH})$ and chronic hemolytic anemia, especially sickle-cell disease. The distinction between $\mathrm{PAH}$ and $\mathrm{PH}$ related to elevated pulmonary venous pressure, however, is less clear. Estimates of PAP based on echocardiographic measurements of tricuspid regurgitation jet velocity have indicated that approximately $30 \%$ of patients with sickle-cell disease have PH. ${ }^{10,11}$ However, catheter-based data indicated that almost half of the patients 
Table 1. Clinical Classification of Pulmonary Hypertension

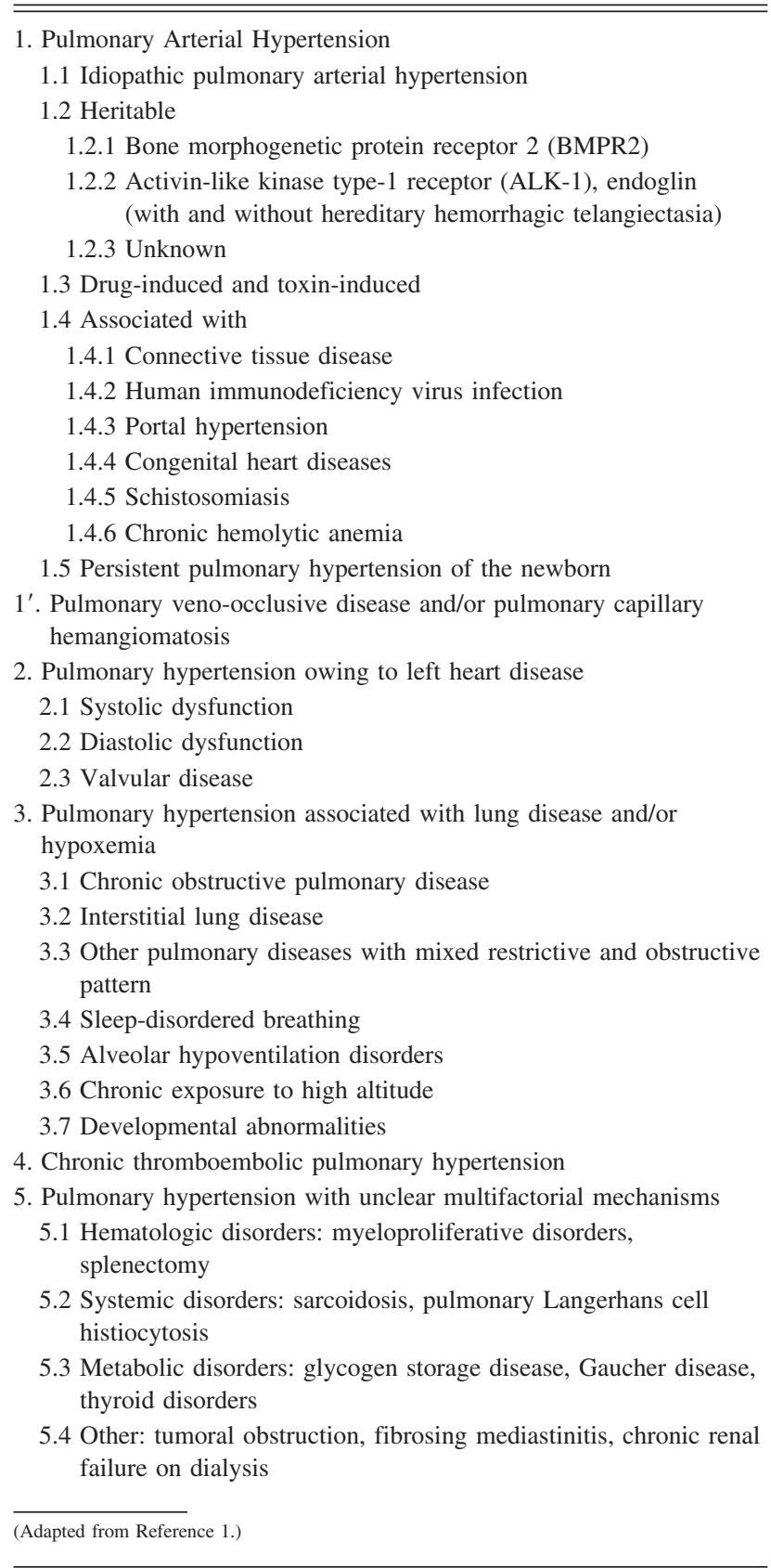

with PH had elevated pulmonary venous pressure or hyperkinetic states that resulted in elevated PAP with normal pulmonary vascular resistance (PVR). ${ }^{10} \mathrm{~A}$ recent study of 50 pediatric patients with sickle-cell disease used Doppler echocardiography combined with respiratory mass spectrometry to calculate pulmonary blood flow and stroke index, and to estimate PVR. Forty-four percent of the children with sickle-cell disease had a tricuspid jet velocity of $\geq 2.5 \mathrm{~m} / \mathrm{s}$ (the definition of $\mathrm{PH}$ in the study), compared to $6 \%$ of age-matched normal controls. However, right-ventricular stroke volume was higher and PVR was lower in patients with sickle-cell disease and $\mathrm{PH}$, compared to controls. $^{12}$

Finally, it is important to recognize that patients may have substantial pulmonary vascular disease without having a resting PAP that meets the definition of PH. ${ }^{13}$ For example, patients with congenital cardiac defects resulting in either increased pulmonary blood flow or impaired pulmonary venous drainage are prone to episodes of acute reactive pulmonary vasoconstriction that can result in catastrophic cardiopulmonary collapse, particularly in the postoperative period after cardiopulmonary bypass. ${ }^{14,15}$

\section{Pathophysiology}

The pathophysiology of $\mathrm{PH}$ is multifactorial, complex, and incompletely understood. Various etiologies are associated with different particular mechanisms of disease, and a unifying construct has not been identified. However, several pathways common to a number of etiologies have been elucidated and have been leveraged in the development of novel and effective therapies.

\section{Hemodynamics and Morphology}

From a hemodynamic standpoint, the morbidity and mortality associated with $\mathrm{PH}$ relates to increased right-ventricular afterload. Over time, compensatory mechanisms fail, leading to right-heart failure and death. It is important to note that the tempo of this clinical sequence differs across etiologies and individual patients. For example, right-ventricular failure can develop rapidly in an infant following cardiac surgery (ie, postoperative pulmonary hypertensive crisis) or may progress over years in other patients (eg, Eisenmenger syndrome).

Although right-ventricular failure is a common final outcome in patients with $\mathrm{PH}$, the pulmonary vascular changes are more diverse and relate to the specific etiology. This is important when considering available therapies, since therapies appropriate for one patient group may be deleterious for another. For example, inhaled nitric oxide (INO) may be effective for patients suffering from acute pulmonary arteriolar constriction (eg, PAH, PH owing to lung disease and/or hypoxia), but may be entirely ineffective or even harmful in patients with pulmonary veno-occlusive disease or left-heart failure. ${ }^{16-18}$

Among the various $\mathrm{PH}$ groups, the mechanisms that result in increased right-ventricular afterload are best understood in PAH. However, left-heart disease is a common cause of $\mathrm{PH}$, at least in adults, ${ }^{19}$ in whom elevated PAP relates to the transmission of elevated left-atrial pressure. PVR may be normal. Although subsets of patients with left-heart disease develop PAH, the associated mechanisms are less well understood, and specific therapies for these patients have not been adequately studied. ${ }^{20-23}$ Likewise, 
the pulmonary vascular changes associated with pulmonary veno-occlusive disease, pulmonary capillary hemangiomatosis, and congenital cardiac defects associated with pulmonary venous obstruction are less well studied, but there are probably important differences from pathologies localized to the precapillary pulmonary vascular bed.24-26

In PAH, increased right-ventricular afterload relates to increased PVR and decreased compliance. ${ }^{27,28}$ Whereas historically hemodynamic assessments focused on measuring PAP and calculating PVR in PH patients, recent data have demonstrated value in measuring pulmonary vascular impedance, which combines resistance and compliance. In fact, some studies have found that impedance better predicts outcomes in $\mathrm{PH}$ patients than isolated measurements of PVR. ${ }^{29-31}$

Increased PVR and decreased compliance in PAH relate to several basic mechanisms: increased pulmonary vascular reactivity, sustained pulmonary vasoconstriction, vascular remodeling, and luminal obstruction due to in situ thrombosis and/or obstructive neointimal and plexiform lesions. Vascular remodeling involves changes of the medium and small pulmonary arteries, including medial wall hypertrophy, adventitial thickening, endothelial proliferation, and the abnormal extension of muscularization to normally non-muscular distal pulmonary arteries. These vascular changes tend to progress in a stepwise fashion, and in severe disease obliterate portions of the pulmonary circulation at the level of the distal precapillary resistance arterioles. It is recognized that this sequence represents a pathologic framework, but that substantial heterogeneity exists in terms of the precise pathology of PAH. ${ }^{32}$ Furthermore, the degree to which these changes are reversible remains unclear, but probably depends in part upon the etiology, and may be influenced by age. ${ }^{33}$ For example, in a seminal study, Rabinovitch and colleagues demonstrated that age at surgery, lung morphometric analysis, and the Heath-Edwards system grade predicted the reversibility of structural and functional pulmonary vascular changes secondary to congenital cardiac defects with increased pulmonary blood flow after surgical repair. ${ }^{34}$ In addition, it must be remembered that even early reversible pulmonary vascular disease can contribute to morbidity and mortality. An important study by Celermajer and colleagues, for example, demonstrated that children with increased pulmonary blood flow due to intracardiac shunting had impaired endothelium-dependent pulmonary vascular relaxation before their baseline PAP or PVR had significantly increased. ${ }^{13}$

$\mathrm{PH}$ associated with lung disease and/or hypoxemia is associated with vascular remodeling similar to $\mathrm{PAH}$, but advanced obstructive plexiform lesions are less common. As expected, chronic thromboembolic PH is caused primarily by intraluminal obstruction.

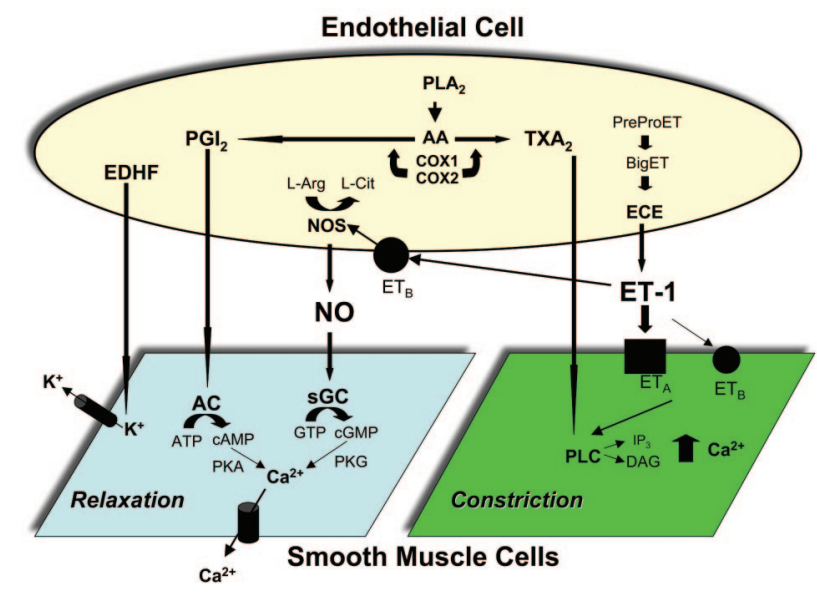

Fig. 1. Some endothelial-derived factors. These factors may increase and/or decrease smooth-muscle cell contraction. $\mathrm{PGI}_{2}=$ prostaglandin $\mathrm{I}_{2}$. $\mathrm{PLA}_{2}=$ phospholipase $\mathrm{A}_{2}$. $\mathrm{AA}=$ arachidonic acid. $C O X=$ cyclo-oxygenase. $T_{X A}=$ thromboxane $A_{2}$. $\mathrm{L}-\mathrm{Arg}=\mathrm{L}$-arginine. $\mathrm{L}-\mathrm{Cit}=\mathrm{L}$-citrulline. $\mathrm{NOS}=$ nitric oxide synthase. $\mathrm{ET}-1$ = endothelin-1. ECE =endothelin converting enzyme. $\mathrm{ET}_{\mathrm{A}}=$ endothelin A receptor. $\mathrm{ET}_{\mathrm{B}}=$ endothelin $\mathrm{B}$ receptor. $\mathrm{NO}=\mathrm{ni}-$ tric oxide. $\mathrm{sGC}=$ soluble guanylate cyclase. GTP = guanosine5' -triphosphate. cGMP = cyclic guanosine-3'-5' monophosphate. $\mathrm{AC}=$ adenylate cyclase. ATP $=$ adenosine $-5^{\prime}$-triphosphate. cAMP $=$ cyclic adenosine- $3^{\prime}-5^{\prime}-$ monophosphate. $\mathrm{PKA}=$ protein kinase $\mathrm{A}$. $\mathrm{PKG}=$ protein kinase $\mathrm{G}$. PLC = phospholipase $\mathrm{C}$. $\mathrm{AMP}=$ adenosine monophosphate. $\mathrm{PDE}=$ phosphodiesterase (type 3 and 5 shown). $\mathrm{K}^{+}=$potassium channels. DAG = diacyl glycerol.

\section{Pulmonary Vascular Endothelium}

Over the past 3 decades, an expansive body of literature has developed that has firmly established the central role of the pulmonary vascular endothelium in the pathophysiology of PH. In 1980, Furchgott and Zawadzki demonstrated for the first time the obligatory role of the vascular endothelium in systemic arterial smooth-muscle relaxation in response to acetylcholine. ${ }^{35}$ Subsequently it was shown that systemic and pulmonary vascular endothelial cells elaborate a number of factors that mediate both vascular smoothmuscle cell relaxation and constriction (Fig. 1).

It is now accepted that increased pulmonary vasoconstriction in $\mathrm{PH}$ is mediated in large part by aberrant endothelial function, wherein endogenous vasodilators, such as nitric oxide and prostacyclin $\left(\mathrm{PGI}_{2}\right)$, are decreased while endogenous vasoconstrictors, such as ET-1 and serotonin (5-HT), are increased (see Fig. 1). ${ }^{36-41}$ Indeed, the majority of approved therapies for $\mathrm{PH}$ target these endothelial-derived factors or their signaling pathways.

Nitric oxide is produced in the vascular endothelium by the enzyme endothelial nitric oxide synthase (eNOS), from the precursor L-arginine. Once formed, nitric oxide diffuses into the adjacent smooth-muscle cell and activates soluble guanylate cyclase (sGC), producing guanosine-3'- 


\section{Advances in the Management of Pediatric Pulmonary Hypertension}

5'cyclic monophosphate (cGMP), which results in smoothmuscle cell relaxation through protein kinase G. cGMP is broken down by a family of phosphodiesterases (PDE). PDE5 is prominent in the pulmonary vasculature.

Arachidonic acid metabolism within vascular endothelial cells results in the production of $\mathrm{PGI}_{2}$ and thromboxane $\left(\mathrm{TXA}_{2}\right) . \mathrm{PGI}_{2}$ activates adenylate cyclase, resulting in increased cyclic adenosine- 3 '-5'-monophosphate (cAMP) production, activation of protein kinase $\mathrm{A}$, and consequent vasodilation, whereas $\mathrm{TXA}_{2}$ results in vasoconstriction via phospholipase $\mathrm{C}$ signaling. $\mathrm{PGI}_{2}$ also binds to platelet receptors, which inhibits their activation.

ET-1 is a 21 amino acid polypeptide that is also produced by vascular endothelial cells. ${ }^{42}$ The vasoactive properties of ET-1 are complex. ${ }^{43-47}$ However, its most striking property is its sustained hypertensive action. The hemodynamic effects of ET-1 are mediated by at least 2 distinct receptor populations: $\mathrm{ET}_{\mathrm{A}}$ and $\mathrm{ET}_{\mathrm{B}} \cdot{ }^{48,49}$ The $\mathrm{ET}_{\mathrm{A}}$ receptors are located on vascular smooth-muscle cells and mediate vasoconstriction, whereas the $\mathrm{ET}_{\mathrm{B}}$ receptors are located on endothelial and smooth-muscle cells and thus may mediate both vasodilation and vasoconstriction, respectively.

An important area of active research is focused on understanding the mechanisms responsible for endothelial injury or dysfunction in PH. Some important mechanisms include alterations in mechanical forces (such as increased pulmonary blood flow associated with congenital cardiac defects, or altered flow velocities that are associated with areas of luminal narrowing) that result in increased vascular-wall shear stress, hypoxia, oxidative stress, and inflammation. ${ }^{50-58}$ Additional factors that contribute to endothelial injury in some patients include, infection, such as HIV and schistosomiasis, and injury from drugs or toxins. ${ }^{59-61}$

Moreover, endothelial-derived factors, such as $\mathrm{NO}, \mathrm{PGI}_{2}$, and ET-1, are integral to processes beyond the regulation of vascular smooth-muscle cell tone. Nitric oxide is a key regulator of vascular homeostasis and also has anti-thrombotic and anti-proliferative properties. Conversely, the mitogenic properties of ET-1 are well described. Indeed, endothelial injury or dysfunction probably contributes to alterations in inflammatory cascades, growth factors, and transcriptional factors that are increasingly recognized as key mediators of the vascular remodeling associated with PH. ${ }^{58}$ For example, alterations in platelet-derived growth factor (PDGF) and vascular endothelial growth factor (VEGF) contribute to abnormal smooth-muscle cell proliferation. ${ }^{62-65}$ Experimental models indicate important interactions between these factors. For example, in a rat model, VEGF inhibition impaired lung growth and resulted in PH: a result that can be reversed with nitric oxide. ${ }^{66}$ Finally, a disrupted endothelium is probably re- sponsible, at least in part, for an increased propensity for intravascular thrombosis.

\section{Pulmonary Vascular Smooth Muscle}

Considerable efforts have been made to understand the processes responsible for the smooth-muscle cell hypertrophy and proliferation that accompany PH. Some known mechanisms include increased pericyte differentiation, smooth-muscle cell migration, endothelial cell transdifferentiation, smooth-muscle cell proliferation, smooth-muscle cell hypertrophy, and inflammation. ${ }^{67,68}$ However, increasing attention is now focused on also understanding potential alterations in the mechanisms that regulate smooth-muscle cell contraction. Myosin light chain (MLC) regulates smooth-muscle cell contraction. Myosin light chain kinase (MLCK) is responsible for the phosphorylation of MLC, leading to an increase in its activity, and myosin light chain phosphatase (MLCP) is responsible for the dephosphorylation of MLC. The activity of MLCK is regulated by $\mathrm{Ca}^{2+}$-calmodulin binding, so an increase in intracellular $\mathrm{Ca}^{2+}$ increases smooth-muscle cell contraction. Vasoconstrictors, such as ET-1 and thromboxane, increase inward $\mathrm{Ca}^{2+}$ flux by binding to G-protein coupled receptors.

In addition to $\mathrm{Ca}^{2+}$ concentration increase, contraction can be augmented by an increase in $\mathrm{Ca}^{2+}$ sensitization. RhoA is a small G-protein that activates downstream effectors, including the Rho kinases (ROCKs). One target of ROCK is myosin phosphatase target subunit (MYPT-1), which is the regulatory subunit of MLCP. Phosphorylation of MYPT-1 results in MLCP inhibition, decreased MLC dephosphorylation, and increased smooth-muscle cell contraction, at any given $\mathrm{Ca}^{2+}$ concentration. Beyond contraction, ROCKs appear to be important in smooth-muscle cell differentiation, proliferation, migration, and apoptosis. ${ }^{69}$ In fact, ROCKs have been shown to participate in vascular endothelial processes as well. ${ }^{69}$ Interest in Rho kinase inhibitors as a treatment for $\mathrm{PH}$ is increasing as positive results have been obtained from multiple animal studies. ${ }^{70-75}$

\section{Genetics}

It is now clear that underlying genetic abnormalities participate in the development of $\mathrm{PH}$ in some patients. Most prominently, mutations in bone morphogenetic protein receptor 2 (BMPR2) are associated with PAH in subsets of patients with and without a family history of disease. ${ }^{76-81}$ On the other hand, a minority (approximately $20 \%$ ) of patients with BMPR2 mutations develops PAH, suggesting that the mutation alone is not sufficient to cause disease in most cases. ${ }^{80,82}$ The bone morphogenetic proteins are members of the transforming growth factor- $\beta$ 
superfamily. ${ }^{77}$ The BMPR2 gene is located on chromosome $2 \mathrm{q} 33$, and multiple mutations have been identified. Inheritance patterns indicate autosomal dominant disease with incomplete penetrance and genetic anticipation. Estimates of BMPR2 mutation in pediatric PH vary, but a recent study that included 78 children with idiopathic $\mathrm{PH}$ identified 8 patients with BMPR2 mutations, and indicated that in adults and children BMPR2 mutations were associated with increased disease severity. ${ }^{83,84}$ Less common genetic associations include mutations in the activin-like kinase type-1 receptor (ALK-1) and endoglin genes. ${ }^{85,86}$

\section{Management Strategies and Therapeutic Options}

The goals of therapy depend on the clinical situation, but basic elements of PH management can be distinguished and applied as appropriate. These include the prevention and/or treatment of active pulmonary vasoconstriction, the support of right-ventricle function, treatment of the underlying disease (if possible), and the promotion of regressive remodeling of structural pulmonary vascular changes. Of course these aims are interrelated, but certain therapies may target one aim more than another in given patients. Table 2 summarizes the therapies described below.

\section{Prevention and/or Treatment of Active Pulmonary Vasoconstriction}

Increased pulmonary vascular reactivity is an early feature of $\mathrm{PH}$, which manifests clinically as augmented pulmonary vasoconstriction in response to such stimuli as hypoxia, acidosis, catecholamine-mediated $\alpha_{1}$-adrenergic stimulation associated with pain and/or agitation, and increases in intrathoracic pressure. .7-89 $^{-19}$

In critical care settings, acute life-threatening pulmonary hypertensive crises are often first treated with pain control, sedation, oxygenation, and alkalinization. Studies in newborn lambs found dose-dependent pulmonary vasodilation in response to increasing $\mathrm{pH}$, from 7.30 to 7.60 , and dose-dependent response to increasing $\mathrm{F}_{\mathrm{IO}_{2}}$, from 0.21 to $0.50 .{ }^{90}$ Indeed, recently published clinical practice guidelines for the hemodynamic support of pediatric and neonatal septic shock specifically address the risk of elevated PAP/PVR and right-heart failure in neonates with sepsis, and the potential need for metabolic and respiratory alkalinization as a part of the initial resuscitation strategy. ${ }^{91}$ However, chronically, such therapies can be detrimental. For example, aggressive hyperventilation and oxygenation can promote the development of secondary lung injury in neonates with PPHN. ${ }^{92,93}$ As such, gentle ventilation, with mild permissive hypercapnia, lower $\mathrm{F}_{\mathrm{IO}_{2}}$, and INO with or without high-frequency ventilation, has become accepted practice for neonates with severe PPHN. ${ }^{93-95}$
Acute selective pulmonary vascular relaxation may be the primary therapeutic goal in some types of $\mathrm{PH}$, such as severe PPHN or postoperative PH. On the other hand, in many other forms of $\mathrm{PH}$, particularly chronic advanced $\mathrm{PH}$, active vasoconstriction is not a prominent pathologic feature. For example, studies of pediatric patients with chronic $\mathrm{PH}$ have found a wide range of responsiveness to acute vasodilator testing, ranging from $7 \%$ to $40 \% .4,96$ The proportion of adults with chronic $\mathrm{PH}$ who respond to acute vasodilators is probably even less. ${ }^{97}$

Endothelial-Based Therapies. The most widely used PH therapies work by altering one of 3 endothelial signaling cascades: nitric oxide-cGMP, $\mathrm{PGI}_{2}$, or ET-1. Figure 2 is a simplified depiction of the various sites of action of the therapies.

Nitric Oxide-cGMP Cascade: Inhaled Nitric Oxide. INO is the best-studied and most widely used agent for acute selective pulmonary vasodilation. When delivered via inhalation, nitric oxide diffuses across the alveolus into the smooth muscle of the accompanying capillary, resulting in relaxation. Nitric oxide then diffuses into the blood vessel, where it is rapidly inactivated by its interaction with hemoglobin. In this way, the effects of INO are relatively confined to the pulmonary circulation and to ventilated areas of the lung, thus optimizing ventilation-perfusion matching. In large trials, INO decreased the need for extracorporeal life support in neonates with PPHN, and those data led to INO's FDA approval. ${ }^{98-100}$ Now INO is used to treat many other forms of $\mathrm{PH}$, and for diagnosis. For example, several studies have investigated INO in pediatric patients undergoing cardiac surgery, ${ }^{15,101-104}$ and found INO effective in lowering PAP and PVR in the postoperative period, but the data were less clear about the impact on outcome. ${ }^{105}$ Likewise, investigators have examined the utility of INO in the particular situations of bidirectional cavopulmonary connections and after Fontan procedure. ${ }^{106-108}$ In those patients, INO decreased central venous pressure and transpulmonary gradient, and increased oxygen saturation. In addition, the pulmonary vascular response to INO has been studied as a part of the assessment for operability in patients with $\mathrm{PH}$ associated with congenital heart disease. ${ }^{109-112}$ Those studies found that the combination of $100 \%$ oxygen and INO (at $80 \mathrm{ppm}$ ) produced maximal pulmonary vasodilation and was more predictive than either treatment alone for postoperative outcome. ${ }^{109-112}$

Nitric Oxide-cGMP Cascade: PDE5 Inhibition. Sildenafil is a PDE5 inhibitor, so its mechanism of action is to augment nitric oxide-cGMP signaling by inhibiting the degradation of cGMP. Increased cGMP results in pulmonary vascular relaxation. Sildenafil has both pulmonary 


\section{Advances in the Management of Pediatric Pulmonary Hypertension}

Table 2. Therapeutic Approach to Pediatric Pulmonary Hypertension

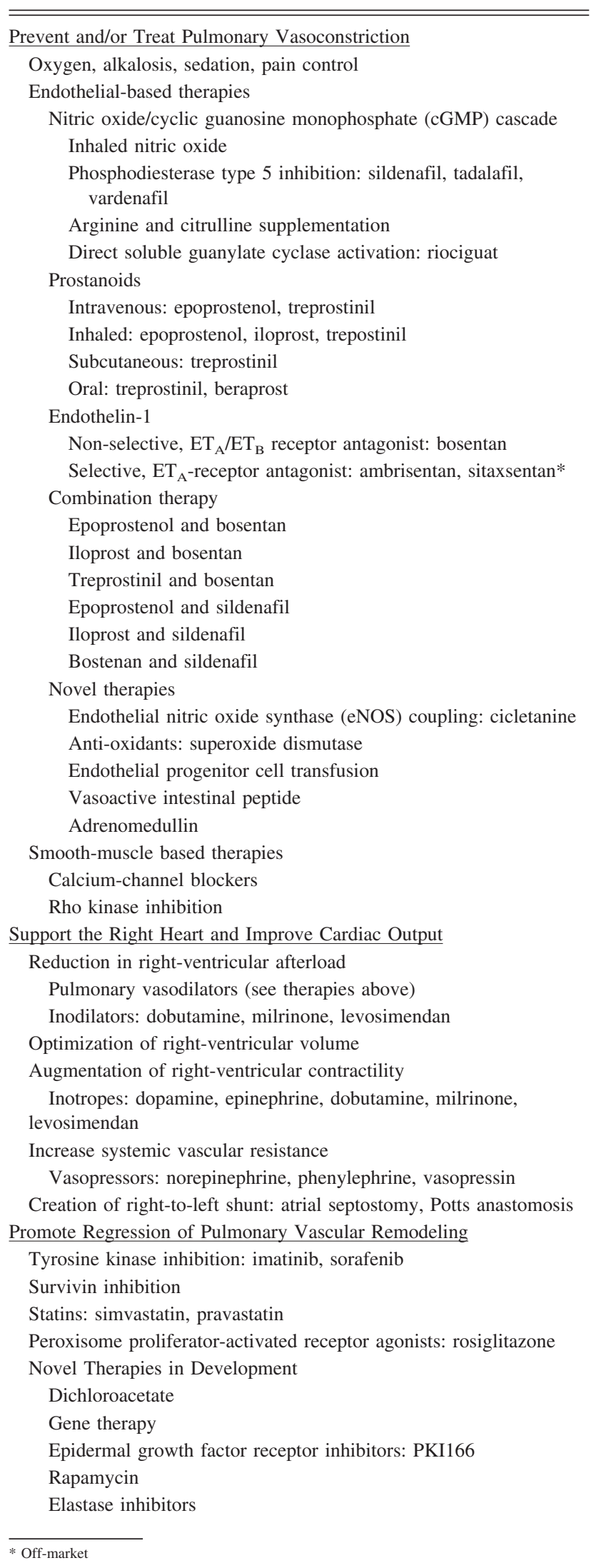

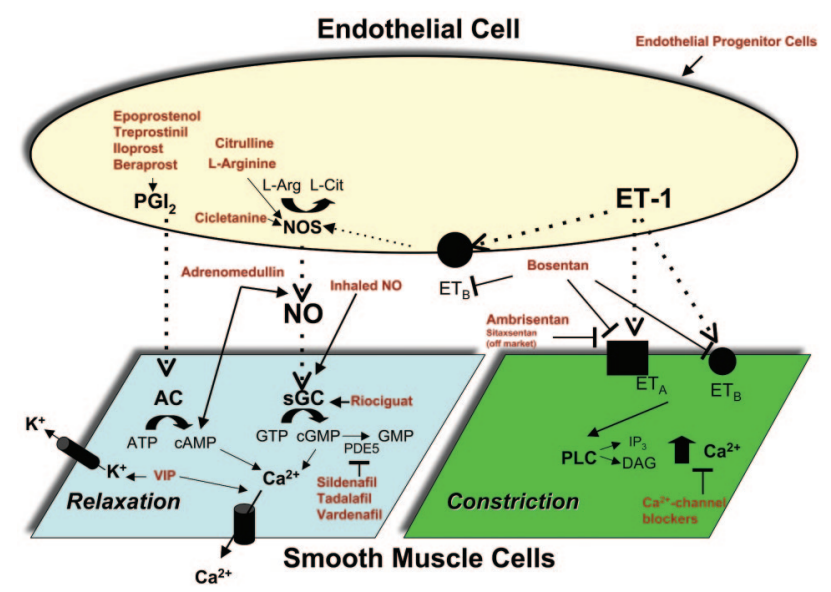

Fig. 2. Sites of action of some endothelial and smooth-muscle cell based therapies. Arrows indicate activation. T symbols indicate inhibition. Terms are as in Figure 1.

and systemic effects, but the importance of this is not yet entirely clear. For example, systemic peripheral vascular relaxation could improve cardiac output, but non-specific pulmonary vascular relaxation could antagonize hypoxic pulmonary vasoconstriction, worsening hypoxia. In addition, the effects of PDE5 inhibition may not be restricted to the vasculature. For example, a recent study found that PDE5 was up-regulated in the hypertrophied right ventricle and that PDE5 inhibition improved contractility. ${ }^{113}$ Randomized placebo-controlled clinical trials, with one that included some pediatric patients, found oral sildenafil effective for the treatment of chronic PAH, in terms of improvements in functional outcomes (eg, 6-minute walk), time to clinical worsening, and hemodynamics. ${ }^{14-117} \mathrm{~A}$ study that enrolled 14 children with PH in an open-label clinical trail of sildenafil found similar results. ${ }^{118}$

Despite limited data, the use of sildenafil in infants and children with PH after cardiac surgery is increasing. Three small studies found that enteral sildenafil facilitated weaning from INO in pediatric patients with congenital heart disease undergoing therapy for postoperative PH. ${ }^{19-121}$ The 2 studies of intravenous sildenafil in pediatric patients after cardiac surgery ${ }^{122,123}$ found both that it decreased PAP and PVR, either to a greater extent than INO or synergistically, but that its use was associated with increased intrapulmonary shunt and decreased systemic arterial pressure.

Sildenafil has also been studied in a placebo-controlled, randomized trial in neonates with severe PPHN. ${ }^{124}$ Thirteen neonates with an oxygenation index of $>25$ received either placebo or enteral sildenafil. The oxygenation index decreased by 30 hours in all 7 sildenafil patients, and 6 of those 7 neonates survived. There was no systemic hypotension in either group. In the placebo group, only 1 of the 6 patients survived. Likewise, in an open-label, dose-es- 
calation trial that included 36 newborns with PPHN and an oxygenation index $>15$ (most of whom were receiving INO), a continuous intravenous infusion of sildenafil for 2-7 days improved oxygenation index by 4 hours at higher doses. ${ }^{125}$

Newer PDE5 inhibitors (ie, tadalafil and vardenafil) offer longer half-lives as the primary potential advantage. In a recent randomized, placebo-controlled, open label study that included patients between 12 and 65 years of age with $\mathrm{PAH}$, vardenafil improved exercise capacity and cardiac index, and decreased PAP and PVR. ${ }^{126}$ However, to date no studies have been published on younger pediatric $\mathrm{PH}$ patients.

Nitric Oxide-cGMP Cascade: Arginine and Citrulline Supplementation. The administration of additional substrate for NOS is another approach to augmenting the nitric oxide-cGMP cascade. A study that included 19 adult patients with $\mathrm{PAH}$, found that oral L-arginine supplementation improved exercise capacity and hemodynamics. ${ }^{127}$ These results confirmed an earlier study of 10 patients with $\mathrm{PAH}$, which found that a short-term intravenous infusion of L-arginine produced a short-term decrease in PAP and PVR. ${ }^{128}$

L-arginine and citrulline levels are decreased in neonates with PPHN, in adults and children with $\mathrm{PH}$ related to sickle-cell disease, and in infants and children after cardiac surgery. ${ }^{129-132}$ In a small study, 5 neonates with PPHN received a single dose of intravenous L-arginine, which decreased the oxygenation index and increased oxygen saturation. ${ }^{133}$ In another study, 10 patients (age range 1363 years) with sickle-cell disease were treated with oral L-arginine for 5 days and had a $15 \%$ decrease in estimated PAP. ${ }^{134}$

A study that included 20 infants with $\mathrm{PH}$ related to cardiac defects with increased pulmonary blood flow examined the effects of an infusion of intravenous L-arginine on hemodynamic variables. ${ }^{135}$ Ten patients were studied preoperatively and another 10 were studied 2 hours after separating from cardiopulmonary bypass in the postoperative period. PVR decreased in both groups in response to oxygen. However, a further decrease in response to L-arginine was seen only in the postoperative group.

Finally, a randomized, double-blind, placebo-controlled trial evaluated the effects of perioperative oral citrulline supplementation in 40 infants and children undergoing cardiac surgery. ${ }^{136}$ Citrulline level above $37 \mu \mathrm{mol} / \mathrm{L}$ appeared to protect against the development of postoperative $\mathrm{PH}$.

Nitric Oxide-cGMP Cascade: Direct Soluble Guanylate Cyclase Activators. Direct activation of sGC is a novel approach that is under investigation for the treatment of $\mathrm{PH}$. A recent study found that $\mathrm{sGC}$ expression was increased in explanted lungs of patients with PAH. ${ }^{137}$ In animal models of PH, sGC expression was similarly upregulated, and direct sGC activation improved hemodynamics and vascular remodeling. ${ }^{137-139}$ A proof-of-concept study was conducted that included 19 adult patients with PH (either PAH or chronic thromboembolic PH) who received the new drug riociguat (BAY 63-251). ${ }^{140,141}$ That study suggested that riociguat was safe and found that pulmonary hemodynamics and cardiac output improved in a dose-dependent fashion. ${ }^{140}$ A subsequent phase II study that included 75 adult patients with PAH or chronic thromboembolic $\mathrm{PH}$ found that riociguat improved exercise capacity and decreased PVR. ${ }^{142}$

Clinical studies in pediatric $\mathrm{PH}$ patients are not yet available. However, because these novel agents can activate sGC independent of NO, they are promising, since a decrease in bioavailable NO appears to be central to the pathophysiology of some forms of PH. In addition, NO binding to sGC is impaired when the heme group on sGC is oxidized. ${ }^{143}$ Interestingly, these agents can function when sGC is in the oxidized state, ${ }^{144}$ which may be important, given growing evidence of the role of oxidative stress in many forms of PH.

Prostanoids. Higenbottam and colleagues first described the long-term use of intravenous $\mathrm{PGI}_{2}$ for the treatment of PH almost 30 years ago. ${ }^{145}$ Despite the many recent advances in therapy, intravenous $\mathrm{PGI}_{2}$, epoprostenol, remains the best-proven and most effective therapy for chronic PH. ${ }^{146-148}$ Yung and colleagues recently described a group of 35 children with idiopathic PAH treated with epoprostenol. ${ }^{149}$ In that cohort, survival at 1 year, 5 years, and 10 years was $94 \%, 81 \%$, and $61 \%$, respectively. This is particularly important given that the median survival in children with primary $\mathrm{PH}$ has been reported to be as low as 10 months without treatment. ${ }^{150}$ Interestingly, studies indicate that patients without an initial vasodilating response to $\mathrm{PGI}_{2}$ often gain important long-term benefit, which suggests that effects beyond vasodilation, such as anti-platelet effects, cAMP-mediated inhibition of smoothmuscle cell growth, or other unknown mechanisms may be responsible for the treatment effect. ${ }^{96}$ Complications associated with long-term epoprostenol are well known and include thrombosis and infection secondary to the required indwelling central venous catheter, the need for dose escalation, and life-threatening rebound $\mathrm{PH}$ after abrupt discontinuation of the infusion.

In addition to epoprostenol, treprostinil is another $\mathrm{PGI}_{2}$ analog that was recently approved for intravenous administration. ${ }^{151}$ Data are not available to compare the efficacy of intravenous epoprostenol to treprostinil. However, Ivy and colleagues reported the successful transition of 13 children from intravenous epoprostenol to treprostinil without changes in exercise capacity or intolerable adverse effects. ${ }^{152}$ 


\section{Advances in the Management of Pediatric Pulmonary Hypertension}

Less is known about the use of intravenous prostanoids in pediatric patients with $\mathrm{PH}$ secondary to other conditions. Rosenzweig and colleagues reported on the use of long-term epoprostenol in 20 children with PH secondary to congenital cardiac defects. PAP and PVR decreased, and cardiac output and exercise capacity increased after one year of therapy. ${ }^{153}$

Given the success of intravenous epoprostenol, recent efforts have focused on developing additional agents and delivery approaches, in large part to address the complications and limitations associated with long-term intravenous infusions. To achieve selective pulmonary vascular relaxation, various investigations have focused on delivering prostanoids via inhalation. ${ }^{154-156}$ In a report on 4 newborns with PPHN refractory to INO, Kelly and colleagues described improved oxygenation with inhaled epoprostenol. ${ }^{155}$ Iloprost is a $\mathrm{PGI}_{2}$ analog that is FDA approved for administration via nebulization. Ivy and colleagues studied iloprost in 22 children with PH. ${ }^{157}$ They found that inhaled iloprost decreased PAP to a degree equivalent to INO with oxygen. A minority of patients (35\%) demonstrated improved functional class, but up to $10 \%$ experienced acute bronchoconstriction. Likewise, Rimensberger and colleagues administered inhaled iloprost and INO, alone and in combination, to 15 children with PH secondary to congenital cardiac defects. ${ }^{158}$ Both agents decreased the PVR/SVR ratio to a similar degree, and there was no added benefit from a combination of the treatments. Furthermore, in an interesting study by Limsuwan and colleagues, in Thailand, which has less access to INO, inhaled iloprost decreased mean PAP and increased systemic saturation without decreasing systemic blood pressure in 8 children suffering from acute PAP increases after repair of congenital heart disease. ${ }^{159}$ In addition, treprostinil, which was initially approved by the FDA for subcutaneous delivery, was recently approved for delivery via inhalation. Several studies have indicated that inhaled treprostinil improves exercise capacity and decreases PVR and PAP in adults with chronic PH. ${ }^{160-162}$ More recently, a randomized controlled trial that included 212 adult patients with PH who were being treated with either bosentan or sildenafil, found that the addition of inhaled treprostinil improved exercise capacity, quality of life, and $\mathrm{N}$-terminal pro-brain natriuretic peptide (NT-proBNP) levels, without changing pulmonary hemodynamics. ${ }^{163}$

Other dosing strategies for prostanoids include subcutaneous and oral administration. A number of studies, including randomized, placebo-controlled clinical trials have demonstrated the efficacy of subcutaneous treprostinil in improving exercise capacity in adults with $\mathrm{PH} .{ }^{164-169} \mathrm{In}$ children, a primary impediment to the use of subcutaneous treprostinil relates to pain at the injection site. Nonetheless, subcutaneous treprostinil has been used successfully in pediatric patients. ${ }^{170,171}$ Finally, oral prostanoid thera- pies are being developed. These include beraprost, which is a $\mathrm{PGI}_{2}$ analog, and an oral formulation of treprostinil. Results with beraprost have been mixed: several clinical trials have shown initial improvement in exercise capacity that may not be sustained over the long term. ${ }^{172-174}$

Endothelin-1. Unlike augmentation of the NO/cGMP and prostanoid cascades, inhibition of endothelin-1 (ET-1) signaling does not reliably cause acute pulmonary vascular relaxation. However, in a small study that included 7 infants who had undergone surgical repair of left-to-right intracardiac shunt, Schulze-Neick and colleagues demonstrated that an intravenous infusion of a selective $\mathrm{ET}_{\mathrm{A}^{-}}$ receptor antagonist resulted in an acute decrease in PVR. ${ }^{175}$ Notably, the addition of INO had no effect, and the decrease in PVR correlated with left-atrial ET-1 level. But, currently, intravenous ET-receptor antagonists are largely restricted to experimental settings.

Bosentan is an oral dual ET-receptor antagonist. Several double-blind, placebo-controlled, randomized clinical trials have confirmed the efficacy of bosentan in adult patients with PAH. ${ }^{176-178}$ These studies found, variously, that bosentan improved pulmonary hemodynamics, exercise capacity, and cardiac output while lengthening the time to clinical worsening.

In a study of 40 children with idiopathic or associated $\mathrm{PAH}$, Maiya and colleagues found that bosentan improved exercise capacity and weight-gain in children with associated PAH, but in only $40 \%$ of children with idiopathic PAH. ${ }^{179}$ Rosenzweig and colleagues performed a retrospective study that included 86 children with idiopathic or associated $\mathrm{PAH},{ }^{7}$ and bosentan was associated with improved WHO functional class in $46 \%$ of the patients.

$\mathrm{ET}_{\mathrm{A}}$ receptors are located on vascular smooth-muscle cells and mediate constriction, but $\mathrm{ET}_{\mathrm{B}}$ receptors may mediate relaxation or constriction, depending on whether they are located on endothelial or smooth-muscle cells, respectively. In addition, $\mathrm{ET}_{\mathrm{B}}$ receptors are involved in the clearance of ET-1. Therefore, there is rationale for $\mathrm{ET}_{\mathrm{A}}$-specific receptor antagonism for the treatment of $\mathrm{PH}$. However, the degree to which $\mathrm{ET}_{\mathrm{B}}$ receptors mediate constriction or relaxation relates to the density of receptors on the smoothmuscle or endothelial cells, and this is a dynamic process. For example, in a lamb model of increased pulmonary blood flow, created by a systemic to pulmonary shunt, $\mathrm{ET}_{\mathrm{B}}$ localization to smooth-muscle cells increased by 8 weeks of age, with an associated increase in $\mathrm{ET}_{\mathrm{B}}$-receptor-mediated pulmonary vasoconstriction. ${ }^{180}$ Moreover, Bauer and colleagues found that $\mathrm{ET}_{\mathrm{B}}$-receptors were selectively up-regulated and appeared to be localized to the hypertrophied medial layer of pulmonary arteries in 14 patients undergoing pulmonary thromboendarterectomy for chronic thromboembolic PH. ${ }^{181}$ 
Two oral $\mathrm{ET}_{\mathrm{A}}$-receptor antagonists have been studied for the treatment of PH: sitaxsentan and ambrisentan. Several studies demonstrated that sitaxsentan was efficacious for the treatment of idiopathic and associated PAH. ${ }^{182-185}$ Unfortunately, sitaxsentan has been taken off of the market, due to concern about hepatic toxicity in some patients. In fact, potential hepatic toxicity is associated with both bosentan and sitaxsentan, which are sulfonamide-based agents and metabolized by cytochrome P450 enzymes. ${ }^{186,187}$ Ambrisentan is a newer oral selective $\mathrm{ET}_{\mathrm{A}^{-}}$ receptor antagonist that is metabolized by hepatic glucuronidation, with less involvement of the P450 enzyme pathway. ${ }^{188}$ Moreover, unlike bosentan and sitaxsentan, ambrisentan does not induce or inhibit the P450 enzymes. ${ }^{188}$ In fact, the successful use of ambrisentan has been reported in patients who discontinued bosentan and sitaxsentan due to elevated hepatic transaminase levels. ${ }^{189}$ Data are not yet available on the efficacy of ambrisentan for children under 12 years of age with $\mathrm{PH}$. However, the results of 2 double-blind, placebo-controlled, randomized trials that were run concurrently were recently reported. ${ }^{182}$ The studies included 202 and 192 adult patients with PAH and found that ambrisentan therapy improved exercise capacity, cardiac index, time to clinical worsening, and Borg dyspnea score, and decreased PAP and B-type natriuretic peptide level.

Combination Therapy. The rationale for combination therapy for PH stems from the discovery of multiple pathways that contribute to the pathophysiology of $\mathrm{PH}$, the need for dose escalation with several therapies coupled with adverse effects at higher doses, and the relatively modest treatment effects of monotherapy without an acceptable impact on mortality.

A number of randomized, placebo-controlled, clinical trials have been conducted on various therapy combinations. The Bosentan Randomized Trial of Endothelin Antagonist Therapy for PAH (BREATHE-2) study included 33 adult patients with $\mathrm{PAH}$, and compared epoprostenol with bosentan to epoprostenol alone. ${ }^{190}$ That study found no benefit, and a trend toward more adverse effects with combination therapy. The STEP-1 trial included 67 adult patients with $\mathrm{PAH}$, and compared bosentan and iloprost to bosentan alone. ${ }^{191}$ There was an improvement in functional class and a delay in time to clinical worsening, but those results were not replicated by the Combination Therapy of Bosentan and Aerosolized Iloprost in Idiopathic Pulmonary Arterial Hypertension (COMBI) trial that compared those same treatments in 40 adult $\mathrm{PAH}$ patients. ${ }^{191,192}$ Channick and colleagues investigated the effects of adding inhaled treprostinil to bosentan therapy in 12 patients with PAH. ${ }^{160}$ That combination improved pulmonary hemodynamics, exercise capacity, and functional class.
The combination of sildenafil and prostanoids has also been investigated. The Pulmonary Arterial Hypertension Combination Study of Epoprostenol and Sildenafil (PACES) trial compared epoprostenol plus sildenafil to epoprostenol alone in 267 adult patients with PAH. ${ }^{193}$ The combination had favorable results, including better exercise capacity, pulmonary hemodynamics, quality of life, and a delay in time to clinical worsening. Likewise, Ghofrani and colleagues investigated the impact of sildenafil in 73 adult patients with PAH who were receiving inhaled iloprost. ${ }^{194}$ The addition of sildenafil improved exercise capacity and pulmonary hemodynamics. In a study meant to capture patients early in the disease course, patients with PAH at a WHO functional class of II were treated with bosentan. A subset of patients was receiving background sildenafil, and they had better pulmonary hemodynamics and time to clinical worsening. ${ }^{195}$ Several other trials have compared various combination therapies, and the preliminary results suggest benefits. Unfortunately, similar randomized trials in pediatric patients are not available, although many pediatric patients receive combination therapy.

\section{Novel Endothelial-Based Therapies.}

eNOS Coupling. A decrease in bioavailable nitric oxide is an important component of endothelial dysfunction in PH. Several factors can decrease the bioavailability of nitric oxide, including decreased production by eNOS. When substrate or cofactors are limited, or due to oxidative stress, eNOS can become uncoupled, and then it produces superoxide anion instead of nitric oxide, ${ }^{54,196}$ which increases oxidative stress. Cicletanine improves eNOS coupling, thereby increasing bioavailable nitric oxide. ${ }^{197,198}$ At this point, the use of cicletanine in $\mathrm{PH}$ is limited to a case report, which described a positive response in an adult. ${ }^{199}$

Superoxide Dismutase. Oxidant stress is well known to contribute to the endothelial dysfunction associated with vascular disease, including PH. ${ }^{54,200}$ Superoxide dismutase, the enzyme responsible for the clearance of superoxide anion, has been used clinically, including in premature infants. ${ }^{201-203}$ Steinhorn and colleagues found that recombinant human superoxide dismutase decreased PVR and was synergistic with INO in a fetal lamb model of PPHN.204

Cell-Based Therapy. In 1997, endothelial progenitor cells (EPCs) were first isolated from human blood, and autologous EPCs were shown to incorporate into vessels during angiogenesis in animal models. ${ }^{205}$ Subsequently, therapeutic administration of EPCs was shown to ameliorate $\mathrm{PH}$ in animal models, with improved efficacy when EPCs were transduced with eNOS. ${ }^{206-208}$ In addition, sev- 
eral studies have found decreased and dysfunctional EPCs in patients with PAH. ${ }^{209,210}$ Wang and colleagues performed a prospective randomized trial to assess the safety and efficacy of adding autologous EPCs infusions to conventional therapy in 31 patients with idiopathic $\mathrm{PH}$, with encouraging results. ${ }^{211}$ Specifically, patients demonstrated improved hemodynamics and exercise capacity, and there were no adverse events during the study period. More recently, that research group performed a pilot study in which 13 children with idiopathic PAH received an infusion of autologous EPCs. ${ }^{212}$ Twelve weeks after treatment the children had a modest PAP decrease, a 19\% PVR decrease, increased cardiac output, improved exercise capacity, and an improvement in functional class.

An intriguing recent study by Smadja and colleagues quantified endothelial colony-forming cells (ECFCs, also called "late EPCs") in 79 children with PAH. ECFCs were increased in the 8 children treated with treprostinil, compared to the rest of the cohort treated with oral ET-1 receptor antagonists and/or PDE5 inhibitors. ${ }^{213}$ In addition, ECFC cultured from these patients demonstrated a hyperproliferative phenotype with increased angiogenic potential.

Novel Vasodilators. Vasoactive intestinal peptide (VIP) and adrenomedullin are 2 peptides with potent vasodilatory properties. A knock-out-mouse model demonstrated that deletion of the VIP gene led to moderate PAH under normoxic conditions. ${ }^{214}$ Moreover, Petkov and colleagues found that VIP was decreased in the serum and lung tissue of patients with $\mathrm{PAH},{ }^{215}$ and inhaled VIP decreased PAP and PVR, and increased cardiac output in 8 patients with PAH. Of note, these patients did not demonstrate a similar response to INO. Furthermore, after 3 months of daily treatment with inhaled VIP, these patients had improved pulmonary hemodynamics, cardiac output, exercise capacity, and Borg dyspnea score. Continued benefit was observed at 6 months, with further improvements in exercise capacity and decreases in the Borg dyspnea index.

Kakishita and colleagues found that adrenomedullin, a peptide with vasodilatory, angiogenic, anti-inflammatory, and anti-proliferative properties, was increased in adult patients with severe $\mathrm{PH}$, and that adrenomedullin level correlated with hemodynamics including right-atrial pressure, stroke volume, PVR, and PAP. ${ }^{216,217}$ Nagaya and colleagues examined the acute effects of inhaled adrenomedullin in 11 adult patients with idiopathic $\mathrm{PH},{ }^{218}$ and adrenomedullin was associated with an acute decrease in PAP and PVR and increase in peak oxygen consumption during exercise.

Anticoagulation. In patients with $\mathrm{PH}$, in situ thrombosis is thought to contribute to pulmonary vascular remodeling and PVR elevation. Studies suggest that warfarin improves survival in patients with $\mathrm{PAH}$, perhaps particularly in those with more advanced disease (ie, those unresponsive to acute vasodilator testing). ${ }^{219-221}$ Aspirin has no proven benefit, and other agents have not been adequately studied.

Smooth-Muscle-Based Therapy. Calcium-channel blockers have long been used as a part of the evaluation and management of PAH, although their use is decreasing. Rich and colleagues demonstrated almost 20 years ago that a subset of patients with idiopathic PH had an acute vasodilatory response to calcium-channel blockers, and that in those patients high-dose calcium-channel blockers improved survival. ${ }^{221}$ More recent data, however, suggested that relatively few patients with idiopathic $\mathrm{PH}$ gain important long-term benefit. ${ }^{97}$ In addition, oxygen and INO have supplanted calcium-channel blockers for acute reactivity testing. Most recently, Montani and colleagues described 663 consecutive patients with associated PAH.222 A minority were responsive to acute vasodilator testing, and even fewer patients demonstrated a long-term response to calcium-channel blockers. In addition, there was variability between conditions. For example, there was a longterm benefit in $9.4 \%$ of acute responders with PAH associated with anorexigen, but less than $1 \%$ with $\mathrm{PAH}$ associated with portal hypertension or connective tissue disease. In fact, all 5 of the patients with pulmonary venoocclusive disease or pulmonary capillary hemangiomatosis who responded to acute vasodilator testing deteriorated with calcium-channel blockers.

Rho-kinase inhibition is a novel therapeutic approach that targets the pulmonary vascular smooth muscle. Alterations in rho-kinase signaling have been demonstrated in several animal models of PH. In addition, Guilluy and colleagues demonstrated increased RhoA and Rho kinase activities in the lungs, platelets, and pulmonary artery smooth-muscle cells harvested from patients with idiopathic PH. ${ }^{223}$ As opposed to endothelial-based therapies, therapy aimed at altering Rho kinase activity has the potential advantage of directly affecting the contractile apparatus of the smooth-muscle cell (Fig. 3). For example, in animal models of severe $\mathrm{PH}$, Rho kinase inhibition resulted in vascular relaxation in animals unresponsive to nitric oxide or $\mathrm{PGI}_{2}$ analogs. 224,225

Clinical data, although limited, have been less impressive. Fujita and colleagues administered fasudil, a Rho kinase inhibitor, and INO to 15 adult patients with PAH.226 In that study, the effects of fasudil and INO were similar: there was a decrease in PAP but not PVR. Li and colleagues investigated the acute effects of an intravenous infusion of fasudil in 12 children (mean age 12.3 years) with PAH associated with congenital heart disease. ${ }^{227} \mathrm{Fa}$ sudil decreased PAP and PVR, and increased cardiac output and mixed venous oxygen saturation. Comparisons to 


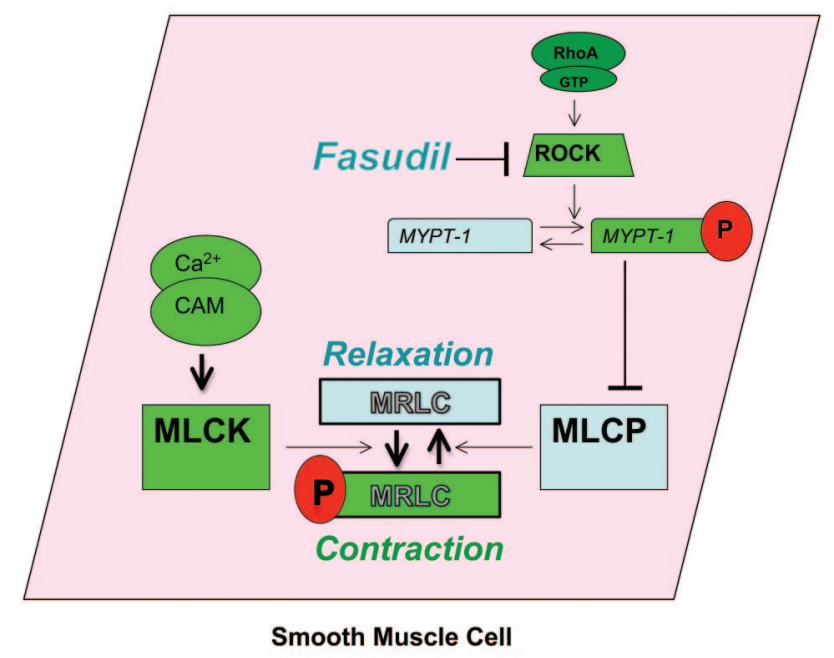

Fig. 3. The mechanism of the rho kinase inhibitor, fasudil. RhoA is a small G-protein that activates downstream effectors, including the rho kinases (ROCKs). One target of ROCK is myosin phosphatase target subunit (MYPT-1), which is the regulatory subunit of myosin light chain (MLCP). Phosphorylation (P) of MYPT-1 results in MLCP inhibition, decreased MLC dephosphorylation, and increased smooth-muscle cell contraction, at any given $\mathrm{Ca}^{2+}$ concentration. By inhibiting ROCK, fasudil blocks this signaling. GTP = guanosine-5' -triphosphate. CAM = calmodulin. MLC = myosin light chain. MLCP = myosin light chain phosphatase. MLCK = myosin light chain kinase.

other vasodilators were not made, however. Likewise, Ishikura and colleagues administered fasudil via intravenous infusion to 8 adult patients with $\mathrm{PAH}$, and found a decrease in PVR and mean PAP, and increased cardiac output. ${ }^{228}$ Finally, Fukumoto and colleagues administered fasudil to 9 adult patients with $\mathrm{PH} .{ }^{229}$ Some patients were receiving oral or intravenous $\mathrm{PGI}_{2}$ at the time of study. The patients underwent right-heart catheterization, which revealed decreased PVR without a significant change in PAP or cardiac output. Together these studies suggest potential efficacy for Rho kinase inhibition in the treatment of PH, but large controlled trials are needed.

\section{Support of Right-Ventricular Function}

Mortality from PH is most directly related to right-ventricular function. The therapies outlined above may improve right-ventricular function to the extent that they decrease right-ventricular afterload, although emerging data suggest that some of these therapies, such as PDE5 inhibition and ET-1 receptor antagonism, may also enhance or impair (respectively) contractility of the hypertrophied right ventricle. ${ }^{13,230}$ However, in addition to afterload reduction, other therapies that support the right ventricle may be necessary, especially in acute care settings.
Under conditions of increased afterload, the contractility of right-ventricular cardiomyocytes increases initially, due to changes in sarcomere length/tension relationships, increased $\mathrm{Ca}^{+2}$ sensitivity, and alterations in force/frequency relationships. ${ }^{231,232}$ In addition, the time course over which right-ventricular afterload increases and the state of the right ventricle (in particular, right-ventricular mass) influences the degree to which the right ventricle can compensate. ${ }^{233}$ For example, patients with Eisenmenger syndrome tolerate elevated right-ventricular afterload far better than patients with normal right ventricles who suffer an acute pulmonary embolism. ${ }^{231,234}$

Nonetheless, over some period of time (acutely or chronically) compensatory mechanisms fail, leading to elevations in right-ventricular end-diastolic volume and decreased output. Due to ventricular interdependence, increases in right-ventricular end-diastolic volume result directly in decreased left-ventricular filling and decreased systemic output. ${ }^{235}$ In fact, diastolic ventricular interactions, with decreases in left-ventricular end-diastolic volume, are more closely related to stroke volume than PAP in patients with PAH. ${ }^{236}$ It is also important to recognize that right and left-ventricular contractility are directly related. The ventricles share muscle fibers, the interventricular septum, and the pericardial space. Based on studies that used electrically-isolated right-heart preparations and experimental aortic constriction, it is estimated that 20$40 \%$ of right-ventricular systolic pressure is due to leftventricular contraction. ${ }^{237-239}$ In addition, right coronary artery perfusion is dependent, in large part, on the pressure gradient between the aortic root and right ventricle.

Taken together, then, the principles of right-ventricular support are: reduce right-ventricular afterload (ie, reduce pulmonary vascular impedance); optimize right-ventricular volume; augment right-ventricular contractility; and maintain left-ventricular contractility and systemic vascular resistance. Importantly, this strategy requires adequate left-ventricular function. The physiology associated with $\mathrm{PH}$ due to left-heart failure is quite different. Left-heart failure is associated with elevated left-ventricular end-diastolic volume and pressure, which is the reverse situation of right-heart failure due to PAH. Moreover, in this situation, decreased right-ventricular afterload and/or increased systemic vascular resistance could result in clinical deterioration, with pulmonary edema or impaired cardiac output. ${ }^{16,17,240}$ Interestingly, however, sildenafil has been shown to increase cardiac output in patients with $\mathrm{PH}$ secondary to left-heart failure, presumably due to reductions in pulmonary and systemic vascular resistance. ${ }^{241,242}$

The optimization of right-ventricular volume presents a substantial clinical challenge, as the proper management is dependent on the particular situation. ${ }^{243-248} \mathrm{Al}-$ though volume loading may be necessary in some situations, excessive volume may provoke adverse diastolic 
ventricular interactions. Management aimed at decreasing right-ventricular volume (eg, diuretics) may be necessary. 248,249

Inotropes are often necessary in order to augment rightventricular contractility, but it remains unclear if one agent is superior. Although dopamine has been shown to increase cardiac output in patients with $\mathrm{PH}$, Liet and colleagues found that dopamine increased the ratio of PVR to systemic vascular resistance in preterm infants who had a widely patent ductus arteriosus. ${ }^{250,251}$ Based on animal studies, epinephrine may have a superior hemodynamic profile in the setting of $\mathrm{PH}$, compared to dopamine, including a decrease in the PVR to systemic vascular resistance ratio, but direct clinical evidence is sparse. ${ }^{252}$ Low-dose dobutamine may reduce PVR and increase right-ventricular contractility. Several clinical studies have demonstrated the efficacy of dobutamine in adult patients with PH. ${ }^{253-255}$ Likewise, milrinone, a PDE3 inhibitor and inodilator that augments ventricular contractility while decreasing PVR and systemic vascular resistance, improves right-ventricular output in adult patients with PH. ${ }^{256-258}$ The decrease in systemic vascular resistance may not be desirable and thus may need to be addressed by the addition of a vasopressor. Finally, the drug levosimendan, which is a $\mathrm{Ca}^{2+}$ sensitizing agent and PDE3 inhibitor, holds great promise. Levosimendan decreases PVR and improves right-ventricular output in adult patients with right-ventricular failure secondary to several conditions, including PH.259-263

The role of vasopressors is to increase systemic vascular resistance to augment right-ventricular output by increasing left-ventricular systolic pressure, and to maintain right coronary perfusion. Norepinephrine has been validated as a useful agent in several animal studies. ${ }^{264,265}$ Tourneux and colleagues demonstrated that norepinephrine increased left-ventricular output, systemic arterial pressure, and pulmonary blood flow, while decreasing the ratio of pulmonary to systemic pressure in 18 newborns with PPHN. ${ }^{266}$ Phenylephrine increases right coronary blood flow in the setting of increased right-ventricular pressure, but may also increase PVR. ${ }^{267,268}$ Vasopressin, a systemic vasoconstrictor and pulmonary vasodilator, has been advocated in the treatment of right-ventricular failure secondary to $\mathrm{PH}$, with several positive clinical studies. ${ }^{269-274}$

Finally, atrial septostomy as a part of the management of chronic PH has been advocated to allow for decompression of the right ventricle due to right-to-left shunting. ${ }^{262,275-280}$ Severe hypoxemia with this approach remains a concern. Recently, Labombarda and colleagues described favorable results with the placement of a Potts anastomosis (descending aorta to left pulmonary artery) in 2 children with severe idiopathic $\mathrm{PH}$, thereby directing desaturated blood to the lower body. ${ }^{281}$

\section{Treatment of Underlying Disease}

The ability to impact the course of PH by treating associated conditions is highly variable. Early repair of congenital cardiac defects represents the most successful effort to alter the natural history of PH. ${ }^{34,87,282,283}$ Likewise, $\mathrm{PH}$ related to treatable left-heart disease would be expected to resolve in most cases, depending on the timing of the repair. However, treatment for other associated conditions may not decrease the incidence of PH. For example, PH can develop with schistosomiasis and HIV infection, despite treatment. ${ }^{284,285}$ The reversal of $\mathrm{PH}$ associated with portal hypertension after liver transplant has been described, but not in a large series. ${ }^{286,287}$ Likewise, the reversal of $\mathrm{PH}$ associated with systemic lupus erythematosus after hematopoietic stem-cell transplantation has been described, but only in case reports. ${ }^{288}$ Steroids have been successful in treating some patients with autoimmune disease, mixed connective-tissue disease, POEMS (polyneuropathy, organomegaly, endocrinopathy, monoclonal gammopathy, and skin changes) syndrome, Langerhans cell granulomatosis, and sarcoidosis. ${ }^{289-293}$ Advances in the management of sickle-cell disease may decrease the incidence of associated $\mathrm{PH}$, but definitive studies are lacking. ${ }^{294}$

Subsets of newborns with PPHN are often treatable, and can ultimately survive without PH. ${ }^{295}$ Several reports have described the reversal of PH after tonsillectomy or adenoidectomy for the treatment of obstructive sleep apnea. ${ }^{296-298}$ In addition, PH related to high altitude can be reversed when the patient moves to sea level. ${ }^{299}$ Home oxygen therapy is a relatively common treatment for pediatric patients with $\mathrm{PH}$ or at risk for developing $\mathrm{PH}$, but the data conflict about whether oxygen therapy alters the disease course, probably due to differences between the diseases that have been studied. ${ }^{300,301}$

Finally, an increasing number of metabolic conditions have been found to be associated with PH. For example, the association between thyroid disorders and $\mathrm{PH}$ is now well established and, in fact, therapy has been shown to reverse $\mathrm{PH}$ in these patients. ${ }^{302}$

\section{Promotion of Regressive Remodeling of Structural Pulmonary Vascular Changes}

Right-heart failure due to elevated pulmonary vascular impedance is the ultimate cause of mortality in most patients with PH. The majority of patients with advanced disease do not respond to acute pulmonary vasodilators, and yet most available therapies either augment pathways that cause vasodilation or inhibit pathways that cause vasoconstriction. Taken together, it can be seen that an approach aimed at promoting the regression of structural pulmonary vascular remodeling may be a fundamentally more effective paradigm for patients with $\mathrm{PH}$ not associ- 
ated with treatable conditions or with advanced PH. Fortunately, although such therapies are unavailable currently, they may be on the horizon.

Recent insights into the mechanisms responsible for advanced pulmonary vascular remodeling have demonstrated interesting similarities to neoplasia. Thus, signaling pathways of interest in cancer research have been studied in models of PH. Indeed, pulmonary vascular remodeling is known to involve abnormalities in proliferation, cell migration, and apoptosis. In addition, pulmonary vascular remodeling also involves processes related to inflammation.

Tyrosine Kinase Inhibitors. An important recent study examined the efficacy of imatinib mesylate, a tyrosine kinase inhibitor, in patients with $\mathrm{PH}$ refractory to other therapies. ${ }^{303}$ Imatinib, which was developed for the treatment of leukemia, inhibits PDGF receptor, which has been implicated in the pathobiology of advanced PAH. ${ }^{63}$ Imatinib reversed advanced $\mathrm{PH}$ in a monocrotaline rat model and a chronic hypoxia mouse model, ${ }^{63}$ so Ghofrani and colleagues evaluated oral imatinib in a 24-week randomized, double-blind, placebo-controlled phase II study that included 59 adult patients with PAH. ${ }^{303}$ Imatinib decreased PVR and increased cardiac output compared to placebo. These results are intriguing, although much more work is needed to assess the potential impact on pulmonary vascular remodeling.

Likewise, sorafenib inhibits the serine/threonine kinases Raf-1 and b-Raf, in addition to PDGF receptor, VEGF receptor, c-Kit, and Flt-3. ${ }^{304}$ Raf-1 is a key downstream effector for mitogen-activated protein kinase signaling, and in this way may participate in the regulation of proliferation and apoptosis. PDGF, VEGF receptors, c-Kit, and Flt-3 are involved in angiogenesis. Thus, sorafenib has potential for the treatment of vascular remodeling in $\mathrm{PH}$. Indeed, in an experimental rat monocrotaline model, sorafenib improved hemodynamics, reversed pulmonary vascular remodeling, and decreased right-ventricular mass to a greater extent than both imatinib and vehicle control. ${ }^{305}$

Survivin. Survivin is a member of the "inhibitor of apoptosis" family that is ubiquitous in cancer, but not normal, cells. ${ }^{306}$ Interestingly, McMurtry and colleagues, found that survivin was expressed in the pulmonary arteries of 6 patients with PAH. ${ }^{307}$ The same study found that survivin was similarly increased in the pulmonary arteries of rats with a monocrotaline-induced model of $\mathrm{PH}$, and that gene therapy with a dominant-negative survivin mutant reversed vascular remodeling, improved hemodynamics, decreased right-ventricular hypertrophy, and prolonged survival.

Statins. Statins, or HMG-CoA reductase inhibitors, have been found to positively impact a number of pathways in experimental $\mathrm{PH}$. For example, in both monocrotaline and chronic hypoxia rodent models, statins improved pulmonary hemodynamics and vascular remodeling by improving endothelial function, decreasing inflammation, inducing apoptosis, and decreasing neointimal proliferation. ${ }^{308-315} \mathrm{Kao}$ and colleagues performed an open-label observational study that included 16 adult patients with PAH treated with simvastatin. ${ }^{316}$ Simvastatin appeared to improve exercise capacity and cardiac output while decreasing right-ventricular systolic pressure. Lee and colleagues performed a doubleblind trial in 53 adult patients with COPD and PH, in which patients received pravastatin or placebo for 6 months. ${ }^{317}$ Pravastatin treatment was associated with improvements in exercise capacity and Borg dyspnea score. Systolic PAP decreased in the treatment group. Interestingly, urinary excretion of ET-1 decreased in the treatment group and was correlated with improvements in exercise capacity. These improvements in exercise capacity were not replicated in a more recent trial by Wilkins and colleagues that included 42 patients with PAH, treated with simvastatin for $6-12$ months. ${ }^{318}$ However, the primary outcome in that study was right-ventricular mass measured via cardiac magnetic resonance imaging. Simvastatin initially reduced right-ventricular mass at 6 months in the treatment group, but the effect was not sustained at 12 months. King and Day recently conducted an observational study that included a review of 12 children with $\mathrm{PH}$ treated with simvastatin, ${ }^{319}$ and found no clear benefit from simvastatin.

Peroxisome Proliferator-Activated Receptor Gamma. Peroxisome proliferator-activated receptors (PPARs), which are members of a nuclear hormone receptor superfamily, are rapidly emerging as integral mediators of a wide array of disease processes, including vascular disorders. ${ }^{320}$ Although investigations of the vasculature have focused primarily on the systemic circulation, one study showed that PPAR gamma (PPAR $\gamma$ ), one of the 3 PPAR subclasses, was decreased in lung tissue taken from patients with severe PAH. ${ }^{321,322}$ Subsequently, increasing efforts have been made to evaluate PPAR $\gamma$ as a therapy for $\mathrm{PH}$. Indeed, studies have identified interactions between $\operatorname{PPAR} \gamma$ and multiple mediators that are important in the pathogenesis of pulmonary vascular disease, including nitric oxide, ET-1, $\mathrm{PGI}_{2}$, ROCK, EPCs, asymmetric dimethylarginine, insulin, oxidative stress, and the BMPR2 pathway. ${ }^{322-331}$ PPAR $\gamma$ expression was decreased in several studies that used rodent models of PH, and PPAR $\gamma$ agonist treatment attenuated pulmonary vascular remodeling. ${ }^{32-335}$ In an interesting recent study, Falcetti and colleagues demonstrated that PPAR $\gamma$ expression was enhanced in the medial layer of arteries from patients with idiopathic $\mathrm{PH}$, compared to controls. ${ }^{322}$ Whether that finding conflicts with the previous description of decreased lung tissue expression in advanced $\mathrm{PH}$ is unclear, since the initial 
study did not quantitate expression in the medial muscle layers. ${ }^{321}$ Moreover, those investigators demonstrated that the PPAR $\gamma$ agonist rosiglitazone potentiated, and PPAR $\gamma$ antagonism inhibited, the anti-proliferative effects of treprostinil in pulmonary artery smooth-muscle cells, whereas down-regulation of the IP receptor had no effect.

Emerging Therapies. A number of approaches are emerging that may impact vascular remodeling. Caspases are key regulators of apoptosis and are inhibited by intracellular $\mathrm{K}^{+}$. Voltage-gated $\mathrm{K}^{+}$channels are decreased in patients with PH. ${ }^{336}$ Recent, studies found that the transcription factor nuclear factor of activated T cells (NFAT) was increased in experimental $\mathrm{PH}$, and that inhibition of NFAT increased $\mathrm{K}^{+}$channels, inhibited apoptosis, and reversed the $\mathrm{PH}^{337}$ Recent studies indicate that the signal transducers and activators of transcription (STAT) protein family have binding sites within the promoter regions of the major NFAT isoforms. ${ }^{337}$ The isoform STAT3 promotes the expression of the proto-oncogene, Pim1, which has been linked to proliferation and resistance to apoptosis in some cancers. Moreover, a recent study found that Pim1 expression was increased in human PAH and that inhibition of STAT3-Pim1-NFAT signaling by nebulized Pim1 siRNA reversed monocrotaline-induced $\mathrm{PAH}$ in rats. ${ }^{338}$

Changes in the extracellular matrix of pulmonary vascular walls participate in the vascular remodeling in $\mathrm{PH}$. Cowan and colleagues showed that elastase inhibition completely reversed the hemodynamic and structural changes in experimental PH. ${ }^{339}$ Elastase inhibitors are not available clinically, but inhibitors of downstream mediators, including epidermal growth factor (EGF) receptors, are used clinically to treat cancers. That same group demonstrated that the EGF receptor inhibitor PKI166 attenuated PH in a rat monocrotaline $\mathrm{PH}$ model. ${ }^{340}$

Dichloroacetate is a drug that is used clinically to treat mitochondrial disorders in children. ${ }^{341}$ Interestingly, dichloroacetate reversed the hemodynamic and structural abnormalities in rodent PH models, in part through an activation of mitochondrial-dependent apoptosis. ${ }^{342,343}$

\section{Lung Transplantation}

Isolated lung transplantation, as opposed to requisite heart and lung transplantation, is now a viable option for children with end-staged $\mathrm{PH}$. According to the registry of the International Society of Heart and Lung Transplantation, 173 patients less than 8 years of age underwent lung transplantation for PH between 1990 and 2006. ${ }^{344,345}$ Survival in children at 3 years and 5 years was reported to be $60 \%$ and $50 \%$, respectively, which was similar to that in adults. ${ }^{345}$ Moreover, this recent report suggested that out- comes were improving. Idiopathic $\mathrm{PH}, \mathrm{PH}$ associated with congenital heart disease (including Eisenmenger syndrome), and pulmonary vein stenosis or pulmonary venoocclusive disease are the most common diagnoses in patients who undergo lung transplantation for $\mathrm{PH}^{345}$ The optimal timing for lung transplantation in children with $\mathrm{PH}$ is not clear. A study that included 50 children with $\mathrm{PH}$ found that the value of mean right-atrial pressure multiplied by the indexed PVR independently estimated the probability of death at 1 year and 3 years after cardiac catheterization. Those authors suggested that this composite value might be useful for identifying children who should undergo lung transplantation. ${ }^{346}$

\section{Summary}

Over the past several decades, fundamental advances in pulmonary vascular biology have been translated into effective therapies that have improved the quality of life and prolonged survival for neonates, infants, and children with $\mathrm{PH}$. The challenge remains to better characterize the differences between the clinical conditions that cause $\mathrm{PH}$, in order to devise and tailor specific, more effective therapies. Among clinicians and researchers in the field of $\mathrm{PH}$ it is increasingly recognized that therapies other than endothelial-based vasodilators are needed. Furthermore, it is recognized that large gaps exist between the available preclinical animal models and clinical disease. For example, many experimental therapies have been shown to reverse monocrotaline-induced PAH in rodents, but none of these therapies have had similar effects on advanced structural disease in humans. ${ }^{347}$ In addition, the hemodynamic complexities associated with $\mathrm{PH}$ are now better understood, which will result in the more routine consideration of indices such as vascular shear stress and pulmonary vascular compliance, in addition to measurements of PAP and calculated PVR. Likewise, alterations in these hemodynamic forces are not uniform throughout the pulmonary vasculature, probably differing in important ways, for example, between large proximal arteries and distal arterioles. Technological advances in imaging and improved computational modeling are emerging to address these sorts of considerations. Further research will elucidate the mechanisms responsible for structural remodeling, hopefully with the development of therapies that promote the regression of advanced structural disease. These studies are likely to make use of multiple preclinical animal models (including models of advanced structural disease), with more sophisticated determinations of cardiopulmonary hemodynamics and morphometric analysis. A better understanding of the genetic underpinnings of PH will hopefully lead to the ability to tailor therapy for particular patients and etiologies. It remains to be seen to what extent these advances will contribute to a unifying theory of $\mathrm{PH}$ as op- 


\section{Advances in the Management of Pediatric Pulmonary Hypertension}

posed to a fragmentation of our current conception of $\mathrm{PH}$ into distinct novel disease processes.

\section{REFERENCES}

1. Simonneau G, Robbins IM, Beghetti M, Channick RN, Delcroix M, Denton CP, et al. Updated clinical classification of pulmonary hypertension. J Am Coll Cardiol 2009;54(1 Suppl):S43-S54.

2. Moledina S, Hislop AA, Foster H, Schulze-Neick I, Haworth SG. Childhood idiopathic pulmonary arterial hypertension: a national cohort study. Heart 2010;96(17):1401-1406.

3. Fraisse A, Jais X, Schleich JM, di Filippo S, Maragnes P, Beghetti $\mathrm{M}$, et al. Characteristics and prospective 2-year follow-up of children with pulmonary arterial hypertension in France. Arch Cardiovasc Dis 2010;103(2):66-74.

4. Haworth SG, Hislop AA. Treatment and survival in children with pulmonary arterial hypertension: the UK Pulmonary Hypertension Service for Children 2001-2006. Heart 2009;95(4):312-317.

5. Fasnacht MS, Tolsa JF, Beghetti M. The Swiss registry for pulmonary arterial hypertension: the paediatric experience. Swiss Med Wkly 2007;137(35-36):510-513.

6. Beghetti M, Hoeper MM, Kiely DG, Carlsen J, Schwierin B, Segal ES, et al. Safety experience with bosentan in 146 children 2-11 years old with pulmonary arterial hypertension: results from the European Postmarketing Surveillance program. Pediatr Res 2008; 64(2):200-204.

7. Rosenzweig EB, Ivy DD, Widlitz A, Doran A, Claussen LR, Yung $\mathrm{D}$, et al. Effects of long-term bosentan in children with pulmonary arterial hypertension. J Am Coll Cardiol 2005;46(4):697-704.

8. Walsh-Sukys MC, Tyson JE, Wright LL, Bauer CR, Korones SB, Stevenson DK, et al. Persistent pulmonary hypertension of the newborn in the era before nitric oxide: practice variation and outcomes. Pediatrics 2000;105(1 Pt 1):14-20.

9. Finer NN, Barrington KJ. Nitric oxide for respiratory failure in infants born at or near term. Cochrane Database Syst Rev 2006(4): CD000399.

10. Anthi A, Machado RF, Jison ML, Taveira-Dasilva AM, Rubin LJ, Hunter L, et al. Hemodynamic and functional assessment of patients with sickle cell disease and pulmonary hypertension. Am J Respir Crit Care Med 2007;175(12):1272-1279.

11. Gladwin MT, Sachdev V, Jison ML, Shizukuda Y, Plehn JF, Minter $\mathrm{K}$, et al. Pulmonary hypertension as a risk factor for death in patients with sickle cell disease. N Engl J Med 2004;350(9):886-895.

12. Chaudry RA, Cikes M, Karu T, Hutchinson C, Ball S, Sutherland $\mathrm{G}$, et al. Paediatric sickle cell disease: pulmonary hypertension but normal vascular resistance. Arch Dis Child 2011;96(2):131-136.

13. Celermajer DS, Cullen S, Deanfield JE. Impairment of endothelium-dependent pulmonary artery relaxation in children with congenital heart disease and abnormal pulmonary hemodynamics. Circulation 1993;87(2):440-446.

14. Lincoln CR, Rigby ML, Mercanti C, Al-Fagih M, Joseph MC, Miller GA, et al. Surgical risk factors in total anomalous pulmonary venous connection. Am J Cardiol 1988;61(8):608-611.

15. Miller OI, Tang SF, Keech A, Pigott NB, Beller E, Celermajer DS. Inhaled nitric oxide and prevention of pulmonary hypertension after congenital heart surgery: a randomised double-blind study. Lancet 2000;356(9240): 1464-1469.

16. Semigran MJ, Cockrill BA, Kacmarek R, Thompson BT, Zapol WM, Dec GW, et al. Hemodynamic effects of inhaled nitric oxide in heart failure. J Am Coll Cardiol 1994;24(4):982-988.

17. Loh E, Stamler JS, Hare JM, Loscalzo J, Colucci WS. Cardiovascular effects of inhaled nitric oxide in patients with left ventricular dysfunction. Circulation 1994;90(6):2780-2785.
18. Creagh-Brown BC, Nicholson AG, Showkathali R, Gibbs JS, Howard LS. Pulmonary veno-occlusive disease presenting with recurrent pulmonary oedema and the use of nitric oxide to predict response to sildenafil. Thorax 2008;63(10):933-934.

19. Oudiz RJ. Pulmonary hypertension associated with left-sided heart disease. Clin Chest Med 2007;28(1):233-241.

20. Delgado JF, Conde E, Sanchez V, Lopez-Rios F, Gomez-Sanchez MA, Escribano P, et al. Pulmonary vascular remodeling in pulmonary hypertension due to chronic heart failure. Eur J Heart Fail 2005;7(6):1011-1016.

21. Moraes DL, Colucci WS, Givertz MM. Secondary pulmonary hypertension in chronic heart failure: the role of the endothelium in pathophysiology and management. Circulation 2000;102(14):17181723.

22. Cody RJ, Haas GJ, Binkley PF, Capers Q, Kelley R. Plasma endothelin correlates with the extent of pulmonary hypertension in patients with chronic congestive heart failure. Circulation 1992; 85(2):504-509.

23. Ben Driss A, Devaux C, Henrion D, Duriez M, Thuillez C, Levy BI, et al. Hemodynamic stresses induce endothelial dysfunction and remodeling of pulmonary artery in experimental compensated heart failure. Circulation 2000;101(23):2764-2770.

24. Maeda K, Yamaki S, Yokota M, Murakami A, Takamoto S. Hypoplasia of the small pulmonary arteries in total anomalous pulmonary venous connection with obstructed pulmonary venous drainage. J Thorac Cardiovasc Surg 2004;127(2):448-456.

25. Endo M, Yamaki S, Ohmi M, Tabayashi K. Pulmonary vascular changes induced by congenital obstruction of pulmonary venous return. Ann Thorac Surg 2000;69(1):193-197.

26. Lantuejoul S, Sheppard MN, Corrin B, Burke MM, Nicholson AG. Pulmonary veno-occlusive disease and pulmonary capillary hemangiomatosis: a clinicopathologic study of 35 cases. Am J Surg Pathol 2006;30(7):850-857.

27. Gan CT, Lankhaar JW, Westerhof N, Marcus JT, Becker A, Twisk JW, et al. Noninvasively assessed pulmonary artery stiffness predicts mortality in pulmonary arterial hypertension. Chest 2007; 132(6): 1906-1912.

28. Mahapatra S, Nishimura RA, Sorajja P, Cha S, McGoon MD. Relationship of pulmonary arterial capacitance and mortality in idiopathic pulmonary arterial hypertension. J Am Coll Cardiol 2006; 47(4):799-803.

29. Dyer K, Lanning C, Das B, Lee PF, Ivy DD, Valdes-Cruz L, et al. Noninvasive Doppler tissue measurement of pulmonary artery compliance in children with pulmonary hypertension. J Am Soc Echocardiogr 2006;19(4):403-412.

30. Hunter KS, Lee PF, Lanning CJ, Ivy DD, Kirby KS, Claussen LR, et al. Pulmonary vascular input impedance is a combined measure of pulmonary vascular resistance and stiffness and predicts clinical outcomes better than pulmonary vascular resistance alone in pediatric patients with pulmonary hypertension. Am Heart J 2008;155(1): 166-174.

31. Weinberg CE, Hertzberg JR, Ivy DD, Kirby KS, Chan KC, ValdesCruz L, et al. Extraction of pulmonary vascular compliance, pulmonary vascular resistance, and right ventricular work from singlepressure and Doppler flow measurements in children with pulmonary hypertension: a new method for evaluating reactivity: in vitro and clinical studies. Circulation 2004;110(17):2609-2617.

32. Tuder RM. Pathology of pulmonary arterial hypertension. Semin Respir Crit Care Med 2009;30(4):376-385.

33. Yamaki S, Wagenvoort CA. Comparison of primary plexogenic arteriopathy in adults and children. A morphometric study in 40 patients. Br Heart J 1985;54(4):428-434.

34. Rabinovitch M, Keane JF, Norwood WI, Castaneda AR, Reid L. Vascular structure in lung tissue obtained at biopsy correlated with 


\section{Advances in the Management of Pediatric Pulmonary Hypertension}

pulmonary hemodynamic findings after repair of congenital heart defects. Circulation 1984;69(4):655-667.

35. Furchgott RF, Zawadzki JV. The obligatory role of endothelial cells in the relaxation of arterial smooth muscle by acetylcholine. Nature 1980;288(5789):373-376.

36. Giaid A. Nitric oxide and endothelin-1 in pulmonary hypertension. Chest 1998;114(3 Suppl):208S-212S.

37. Giaid A, Saleh D. Reduced expression of endothelial nitric oxide synthase in the lungs of patients with pulmonary hypertension. N Engl J Med 1995;333(4):214-221.

38. Giaid A, Yanagisawa M, Langleben D, Michel RP, Levy R, Shennib $\mathrm{H}$, et al. Expression of endothelin-1 in the lungs of patients with pulmonary hypertension. N Engl J Med 1993;328(24):1732-1739.

39. Christman BW, McPherson CD, Newman JH, King GA, Bernard GR, Groves BM, et al. An imbalance between the excretion of thromboxane and prostacyclin metabolites in pulmonary hypertension. N Engl J Med 1992;327(2):70-75.

40. Adatia I, Barrow SE, Stratton PD, Miall-Allen VM, Ritter JM, Haworth SG. Thromboxane A2 and prostacyclin biosynthesis in children and adolescents with pulmonary vascular disease. Circulation 1993;88(5 Pt 1):2117-2122.

41. Budhiraja R, Tuder RM, Hassoun PM. Endothelial dysfunction in pulmonary hypertension. Circulation 2004;109(2):159-165.

42. Yanagisawa M, Kurihara H, Kimura S, Tomobe Y, Kobayashi M, Mitsui Y, et al. A novel potent vasoconstrictor peptide produced by vascular endothelial cells. Nature 1988;332(6163):411-415.

43. Bradley LM, Czaja JF, Goldstein RE. Circulatory effects of endothelin in newborn piglets. Am J Physiol 1990;259(5 Pt 2):H1613H1617.

44. Cassin S, Kristova V, Davis T, Kadowitz P, Gause G. Tone-dependent responses to endothelin in the isolated perfused fetal sheep pulmonary circulation in situ. J Appl Physiol 1991;70(3):12281234.

45. Wong J, Vanderford PA, Fineman JR, Chang R, Soifer SJ. Endothelin-1 produces pulmonary vasodilation in the intact newborn lamb. Am J Physiol 1993;265(4 Pt 2):H1318-H1325.

46. Wong J, Vanderford PA, Fineman JR, Soifer SJ. Developmental effects of endothelin-1 on the pulmonary circulation in sheep. Pediatr Res 1994;36(3):394-401.

47. Perreault T, De Marte J. Maturational changes in endotheliumderived relaxations in newborn piglet pulmonary circulation. Am J Physiol 1993;264(2 Pt 2):H302-H309.

48. Arai H, Hori S, Aramori I, Ohkubo H, Nakanishi S. Cloning and expression of a cDNA encoding an endothelin receptor. Nature 1990;348(6303):730-732.

49. Sakurai T, Yanagisawa M, Takuwa Y, Miyazaki H, Kimura S, Goto $\mathrm{K}$, et al. Cloning of a cDNA encoding a non-isopeptide-selective subtype of the endothelin receptor. Nature 1990;348(6303):732735 .

50. Morris CR, Vichinsky EP. Pulmonary hypertension in thalassemia. Ann N Y Acad Sci 2010;1202:205-213.

51. Crosswhite P, Sun Z. Nitric oxide, oxidative stress and inflammation in pulmonary arterial hypertension. J Hypertens 2010;28(2): 201-212.

52. Spiekermann S, Schenk K, Hoeper MM. Increased xanthine oxidase activity in idiopathic pulmonary arterial hypertension. Eur Respir J 2009;34(1):276.

53. Gupte SA, Wolin MS. Oxidant and redox signaling in vascular oxygen sensing: implications for systemic and pulmonary hypertension. Antioxid Redox Signal 2008;10(6):1137-1152.

54. Black SM, Fineman JR. Oxidative and nitrosative stress in pediatric pulmonary hypertension: roles of endothelin-1 and nitric oxide. Vascul Pharmacol 2006;45(5):308-316.
55. Birukov KG. Cyclic stretch, reactive oxygen species, and vascular remodeling. Antioxid Redox Signal 2009;11(7):1651-1667.

56. Durmowicz AG, St Cyr JA, Clarke DR, Stenmark KR. Unilateral pulmonary hypertension as a result of chronic high flow to one lung. Am Rev Respir Dis 1990;142(1):230-233.

57. Ghorishi Z, Milstein JM, Poulain FR, Moon-Grady A, Tacy T, Bennett $\mathrm{SH}$, et al. Shear stress paradigm for perinatal fractal arterial network remodeling in lambs with pulmonary hypertension and increased pulmonary blood flow. Am J Physiol Heart Circ Physiol 2007;292(6):H3006-H3018

58. Hassoun PM, Mouthon L, Barbera JA, Eddahibi S, Flores SC, Grimminger F, et al. Inflammation, growth factors, and pulmonary vascular remodeling. J Am Coll Cardiol 2009;54(1 Suppl):S10S19.

59. Marecki JC, Cool CD, Parr JE, Beckey VE, Luciw PA, Tarantal $\mathrm{AF}$, et al. HIV-1 Nef is associated with complex pulmonary vascular lesions in SHIV-nef-infected macaques. Am J Respir Crit Care Med 2006;174(4):437-445.

60. Graham BB, Mentink-Kane MM, El-Haddad H, Purnell S, Zhang L, Zaiman A, et al. Schistosomiasis-induced experimental pulmonary hypertension: role of interleukin-13 signaling. Am J Pathol; 177(3):1549-1561.

61. Souza R, Humbert M, Sztrymf B, Jais X, Yaici A, Le Pavec J, et al. Pulmonary arterial hypertension associated with fenfluramine exposure: report of 109 cases. Eur Respir J 2008;31(2):343-348.

62. Humbert M, Monti G, Fartoukh M, Magnan A, Brenot F, Rain B, et al. Platelet-derived growth factor expression in primary pulmonary hypertension: comparison of HIV seropositive and HIV seronegative patients. Eur Respir J 1998;11(3):554-559.

63. Schermuly RT, Dony E, Ghofrani HA, Pullamsetti S, Savai R, Roth $\mathrm{M}$, et al. Reversal of experimental pulmonary hypertension by PDGF inhibition. J Clin Invest 2005;115(10):2811-2821.

64. Sakao S, Taraseviciene-Stewart L, Cool CD, Tada Y, Kasahara Y, Kurosu K, et al. VEGF-R blockade causes endothelial cell apoptosis, expansion of surviving $\mathrm{CD} 34^{+}$precursor cells and transdifferentiation to smooth muscle-like and neuronal-like cells. FASEB J 2007;21(13):3640-3652.

65. Abman SH. Impaired vascular endothelial growth factor signaling in the pathogenesis of neonatal pulmonary vascular disease. Adv Exp Med Biol 2010;661:323-335.

66. Tang JR, Markham NE, Lin YJ, McMurtry IF, Maxey A, Kinsella JP, et al. Inhaled nitric oxide attenuates pulmonary hypertension and improves lung growth in infant rats after neonatal treatment with a VEGF receptor inhibitor. Am J Physiol Lung Cell Mol Physiol 2004;287(2):L344-L351.

67. Pak O, Aldashev A, Welsh D, Peacock A. The effects of hypoxia on the cells of the pulmonary vasculature. Eur Respir J 2007;30(2): 364-372.

68. Jeffery TK, Wanstall JC. Pulmonary vascular remodeling: a target for therapeutic intervention in pulmonary hypertension. Pharmacol Ther 2001;92(1):1-20.

69. Loirand G, Guerin P, Pacaud P. Rho kinases in cardiovascular physiology and pathophysiology. Circ Res 2006;98(3):322-334.

70. Nagaoka T, Fagan KA, Gebb SA, Morris KG, Suzuki T, Shimokawa $\mathrm{H}$, et al. Inhaled Rho kinase inhibitors are potent and selective vasodilators in rat pulmonary hypertension. Am J Respir Crit Care Med 2005;171(5):494-499.

71. Fagan KA, Oka M, Bauer NR, Gebb SA, Ivy DD, Morris KG, et al. Attenuation of acute hypoxic pulmonary vasoconstriction and hypoxic pulmonary hypertension in mice by inhibition of Rho-kinase. Am J Physiol Lung Cell Mol Physiol 2004;287(4):L656-L664.

72. McMurtry IF, Bauer NR, Fagan KA, Nagaoka T, Gebb SA, Oka M. Hypoxia and Rho/Rho-kinase signaling. Lung development versus 


\section{Advances in the Management of Pediatric Pulmonary Hypertension}

hypoxic pulmonary hypertension. Adv Exp Med Biol 2003;543: 127-137.

73. Abe K, Shimokawa H, Morikawa K, Uwatoku T, Oi K, Matsumoto $\mathrm{Y}$, et al. Long-term treatment with a Rho-kinase inhibitor improves monocrotaline-induced fatal pulmonary hypertension in rats. Circ Res 2004;94(3):385-393.

74. Nagaoka T, Morio Y, Casanova N, Bauer N, Gebb S, McMurtry I, et al. Rho/Rho kinase signaling mediates increased basal pulmonary vascular tone in chronically hypoxic rats. Am J Physiol Lung Cell Mol Physiol 2004;287(4):L665-L672.

75. Mouchaers KT, Schalij I, de Boer MA, Postmus PE, van Hinsbergh VW, van Nieuw Amerongen GP, et al. Fasudil reduces monocrotaline-induced pulmonary arterial hypertension: comparison with bosentan and sildenafil. Eur Respir J 2010;36(4):800-807.

76. Atkinson C, Stewart S, Upton PD, Machado R, Thomson JR, Trembath RC, et al. Primary pulmonary hypertension is associated with reduced pulmonary vascular expression of type II bone morphogenetic protein receptor. Circulation 2002;105(14):1672-1678.

77. Lane KB, Machado RD, Pauciulo MW, Thomson JR, Phillips JA, 3rd, Loyd JE, et al. Heterozygous germline mutations in BMPR2, encoding a TGF-beta receptor, cause familial primary pulmonary hypertension. The International PPH Consortium. Nat Genet 2000; 26(1):81-84

78. Machado RD, Pauciulo MW, Thomson JR, Lane KB, Morgan NV, Wheeler L, et al. BMPR2 haploinsufficiency as the inherited molecular mechanism for primary pulmonary hypertension. American Journal of Human Genetics 2001;68(1):92-102.

79. Morse JH, Deng Z, Knowles JA. Genetic aspects of pulmonary arterial hypertension. Annals of Medicine 2001;33(9):596-603.

80. Newman JH, Wheeler L, Lane KB, Loyd E, Gaddipati R, Phillips JA 3rd, et al. Mutation in the gene for bone morphogenetic protein receptor II as a cause of primary pulmonary hypertension in a large kindred. N Engl J Med 2001;345(5):319-324.

81. Thomson JR, Machado RD, Pauciulo MW, Morgan NV, Humbert $\mathrm{M}$, Elliott GC, et al. Sporadic primary pulmonary hypertension is associated with germline mutations of the gene encoding BMPR-II, a receptor member of the TGF-beta family. J Med Genet 2000; 37(10):741-745.

82. Thomson J, Machado R, Pauciulo M, Morgan N, Yacoub M, Corris $\mathrm{P}$, et al. Familial and sporadic primary pulmonary hypertension is caused by BMPR2 gene mutations resulting in haploinsufficiency of the bone morphogenetic protein type II receptor. J Heart Lung Transplant 2001;20(2):149.

83. Grunig E, Koehler R, Miltenberger-Miltenyi G, Zimmermann R, Gorenflo M, Mereles D, et al. Primary pulmonary hypertension in children may have a different genetic background than in adults. Pediatr Res 2004;56(4):571-578.

84. Rosenzweig EB, Morse JH, Knowles JA, Chada KK, Khan AM, Roberts KE, et al. Clinical implications of determining BMPR2 mutation status in a large cohort of children and adults with pulmonary arterial hypertension. J Heart Lung Transplant 2008;27(6): 668-674.

85. Chaouat A, Coulet F, Favre C, Simonneau G, Weitzenblum E, Soubrier $\mathrm{F}$, et al. Endoglin germline mutation in a patient with hereditary haemorrhagic telangiectasia and dexfenfluramine associated pulmonary arterial hypertension. Thorax 2004;59(5):446-448.

86. Trembath RC, Thomson JR, Machado RD, Morgan NV, Atkinson C, Winship I, et al. Clinical and molecular genetic features of pulmonary hypertension in patients with hereditary hemorrhagic telangiectasia. N Engl J Med 2001;345(5):325-334.

87. Hoffman JI, Rudolph AM, Heymann MA. Pulmonary vascular disease with congenital heart lesions: pathologic features and causes. Circulation 1981;64(5):873-877.
88. Burrows FA, Klinck JR, Rabinovitch M, Bohn DJ. Pulmonary hypertension in children: perioperative management. Can Anaesth Soc J 1986;33(5):606-628.

89. Wheller J, George BL, Mulder DG, Jarmakani JM. Diagnosis and management of postoperative pulmonary hypertensive crisis. Circulation 1979;60(7): 1640-1644.

90. Heidersbach RS, Johengen MJ, Bekker JM, Fineman JR. Inhaled nitric oxide, oxygen, and alkalosis: dose-response interactions in a lamb model of pulmonary hypertension. Pediatr Pulmonol 1999; 28(1):3-11.

91. Brierley J, Carcillo JA, Choong K, Cornell T, Decaen A, Deymann A, et al. Clinical practice parameters for hemodynamic support of pediatric and neonatal septic shock: 2007 update from the American College of Crit Care Med Crit Care Med 2009;37(2):666-688.

92. Dworetz AR, Moya FR, Sabo B, Gladstone I, Gross I. Survival of infants with persistent pulmonary hypertension without extracorporeal membrane oxygenation. Pediatrics 1989;84(1):1-6.

93. Wung JT, James LS, Kilchevsky E, James E. Management of infants with severe respiratory failure and persistence of the fetal circulation, without hyperventilation. Pediatrics 1985;76(4):488494.

94. Kinsella JP, Truog WE, Walsh WF, Goldberg RN, Bancalari E, Mayock DE, et al. Randomized, multicenter trial of inhaled nitric oxide and high-frequency oscillatory ventilation in severe, persistent pulmonary hypertension of the newborn. The Journal of pediatrics 1997;131(1 Pt 1):55-62.

95. Gupta A, Rastogi S, Sahni R, Bhutada A, Bateman D, Rastogi D, et al. Inhaled nitric oxide and gentle ventilation in the treatment of pulmonary hypertension of the newborn: a single-center, 5-year experience. J Perinatology 2002;22(6):435-441.

96. Barst RJ, Maislin G, Fishman AP. Vasodilator therapy for primary pulmonary hypertension in children. Circulation 1999;99(9):11971208.

97. Sitbon O, Humbert M, Jais X, Ioos V, Hamid AM, Provencher S, et al. Long-term response to calcium channel blockers in idiopathic pulmonary arterial hypertension. Circulation 2005;111(23):3105-3111.

98. Inhaled nitric oxide in full-term and nearly full-term infants with hypoxic respiratory failure. The Neonatal Inhaled Nitric Oxide Study Group. N Engl J Med 1997;336(9):597-604.

99. Clark R, Kueser T, Walker M, Southgate W, Huckaby J, Perez J, et al. Low-dose nitric oxide therapy for persistent pulmonary hypertension of the newborn. Clinical Inhaled Nitric Oxide Research Group. N Engl J Med 2000;342(7):469-474

100. Roberts JD Jr, Fineman JR, Morin FC 3rd, Shaul PW, Rimar S, Schreiber MD, et al. Inhaled nitric oxide and persistent pulmonary hypertension of the newborn. The Inhaled Nitric Oxide Study Group. N Engl J Med 1997;336(9):605-610.

101. Wessel DL, Adatia I, Giglia TM, Thompson JE, Kulik TJ. Use of inhaled nitric oxide and acetylcholine in the evaluation of pulmonary hypertension and endothelial function after cardiopulmonary bypass. Circulation 1993;88(5 Pt 1):2128-2138.

102. Curran RD, Mavroudis C, Backer CL, Sautel M, Zales VR, Wessel DL. Inhaled nitric oxide for children with congenital heart disease and pulmonary hypertension. Ann Thorac Surg 1995;60(6):1765-1771.

103. Russell IA, Zwass MS, Fineman JR, Balea M, Rouine-Rapp K, Brook M, et al. The effects of inhaled nitric oxide on postoperative pulmonary hypertension in infants and children undergoing surgical repair of congenital heart disease. Anesth Analg 1998;87(1):46-51.

104. Day RW, Allen EM, Witte MK. A randomized, controlled study of the 1-hour and 24-hour effects of inhaled nitric oxide therapy in children with acute hypoxemic respiratory failure. Chest 1997; 112(5):1324-1331.

105. Bizzarro M, Gross I. Inhaled nitric oxide for the postoperative management of pulmonary hypertension in infants and children 


\section{Advances in the Management of Pediatric Pulmonary Hypertension}

with congenital heart disease. Cochrane Database Syst Rev 2005(4): CD005055.

106. Goldman AP, Delius RE, Deanfield JE, Miller OI, de Leval MR, Sigston PE, et al. Pharmacological control of pulmonary blood flow with inhaled nitric oxide after the fenestrated Fontan operation. Circulation 1996;94(9 Suppl):II44-II48.

107. Gamillscheg A, Zobel G, Urlesberger B, Berger J, Dacar D, Stein JI, et al. Inhaled nitric oxide in patients with critical pulmonary perfusion after Fontan-type procedures and bidirectional Glenn anastomosis. J Thorac Cardiovasc Surg 1997;113(3):435-442.

108. Cai J, Su Z, Shi Z, Zhou Y, Xu Z, Yang Y. Nitric oxide and milrinone: combined effect on pulmonary circulation after Fontantype procedure: a prospective, randomized study. Ann Thorac Surg 2008;86(3):882-888

109. Balzer DT, Kort HW, Day RW, Corneli HM, Kovalchin JP, Cannon BC, et al. Inhaled Nitric Oxide as a Preoperative Test (INOP Test I): the INOP Test Study Group. Circulation 2002;106(12 Suppl 1):I76-I81.

110. Adatia I, Perry S, Landzberg M, Moore P, Thompson JE, Wessel DL. Inhaled nitric oxide and hemodynamic evaluation of patients with pulmonary hypertension before transplantation. J Am Coll Cardiol 1995;25(7):1656-1664.

111. Atz AM, Adatia I, Lock JE, Wessel DL. Combined effects of nitric oxide and oxygen during acute pulmonary vasodilator testing. J Am Coll Cardiol 1999;33(3):813-819.

112. Barst RJ, Agnoletti G, Fraisse A, Baldassarre J, Wessel DL. Vasodilator testing with nitric oxide and/or oxygen in pediatric pulmonary hypertension. Pediatr Cardiol 2010;31(5):598-606.

113. Nagendran J, Archer SL, Soliman D, Gurtu V, Moudgil R, Haromy A, et al. Phosphodiesterase type 5 is highly expressed in the hypertrophied human right ventricle, and acute inhibition of phosphodiesterase type 5 improves contractility. Circulation 2007;116(3): 238-248.

114. Bharani A, Mathew V, Sahu A, Lunia B. The efficacy and tolerability of sildenafil in patients with moderate-to-severe pulmonary hypertension. Indian Heart J 2003;55(1):55-59.

115. Galie N, Ghofrani HA, Torbicki A, Barst RJ, Rubin LJ, Badesch D, et al. Sildenafil citrate therapy for pulmonary arterial hypertension. N Engl J Med 2005;353(20):2148-2157.

116. Sastry BK, Narasimhan C, Reddy NK, Raju BS. Clinical efficacy of sildenafil in primary pulmonary hypertension: a randomized, placebo-controlled, double-blind, crossover study. J Am Coll Cardiol 2004;43(7):1149-1153.

117. Singh TP, Rohit M, Grover A, Malhotra S, Vijayvergiya R. A randomized, placebo-controlled, double-blind, crossover study to evaluate the efficacy of oral sildenafil therapy in severe pulmonary artery hypertension. Am Heart J 2006;151(4):851. e851-e855.

118. Humpl T, Reyes JT, Holtby H, Stephens D, Adatia I. Beneficial effect of oral sildenafil therapy on childhood pulmonary arterial hypertension: twelve-month clinical trial of a single-drug, openlabel, pilot study. Circulation 2005;111(24):3274-3280.

119. Atz AM, Wessel DL. Sildenafil ameliorates effects of inhaled nitric oxide withdrawal. Anesthesiology 1999;91(1):307-310.

120. Namachivayam P, Theilen U, Butt WW, Cooper SM, Penny DJ, Shekerdemian LS. Sildenafil prevents rebound pulmonary hypertension after withdrawal of nitric oxide in children. Am J Respir Crit Care Med 2006;174(9):1042-1047.

121. Lee JE, Hillier SC, Knoderer CA. Use of sildenafil to facilitate weaning from inhaled nitric oxide in children with pulmonary hypertension following surgery for congenital heart disease. J Intensive Care Med 2008;23(5):329-334.

122. Schulze-Neick I, Hartenstein P, Li J, Stiller B, Nagdyman N, Hubler $\mathrm{M}$, et al. Intravenous sildenafil is a potent pulmonary vasodilator in children with congenital heart disease. Circulation 2003;108(Suppl 1):II167-II173.

123. Stocker C, Penny DJ, Brizard CP, Cochrane AD, Soto R, Shekerdemian LS. Intravenous sildenafil and inhaled nitric oxide: a randomised trial in infants after cardiac surgery. Intensive Care Med 2003;29(11):1996-2003.

124. Baquero H, Soliz A, Neira F, Venegas ME, Sola A. Oral sildenafil in infants with persistent pulmonary hypertension of the newborn: a pilot randomized blinded study. Pediatrics 2006;117(4):1077-1083.

125. Steinhorn RH, Kinsella JP, Pierce C, Butrous G, Dilleen M, Oakes M, et al. Intravenous sildenafil in the treatment of neonates with persistent pulmonary hypertension. J Pediatr 2009;155(6):841-847. e841.

126. Jing ZC, Yu ZX, Shen JY, Wu BX, Xu KF, Zhu XY, et al. Vardenafil in pulmonary arterial hypertension: a randomized, doubleblind, placebo-controlled study. Am J Respir Crit Care Med 2011; 183(12):1723-1729.

127. Nagaya N, Uematsu M, Oya H, Sato N, Sakamaki F, Kyotani S, et al. Short-term oral administration of L-arginine improves hemodynamics and exercise capacity in patients with precapillary pulmonary hypertension. Am J Respir Crit Care Med 2001;163(4):887891.

128. Mehta S, Stewart DJ, Langleben D, Levy RD. Short-term pulmonary vasodilation with $\mathrm{L}$-arginine in pulmonary hypertension. Circulation 1995;92(6):1539-1545.

129. Vosatka RJ, Kashyap S, Trifiletti RR. Arginine deficiency accompanies persistent pulmonary hypertension of the newborn. Biol Neonate 1994;66(2-3):65-70.

130. Morris CR, Kuypers FA, Larkin S, Vichinsky EP, Styles LA. Patterns of arginine and nitric oxide in patients with sickle cell disease with vaso-occlusive crisis and acute chest syndrome. J Pediatr Hematol Oncol 2000;22(6):515-520.

131. Pearson DL, Dawling S, Walsh WF, Haines JL, Christman BW, Bazyk A, et al. Neonatal pulmonary hypertension-urea-cycle intermediates, nitric oxide production, and carbamoyl-phosphate synthetase function. N Engl J Med 2001;344(24):1832-1838.

132. Barr FE, Beverley H, VanHook K, Cermak E, Christian K, Drinkwater $\mathrm{D}$, et al. Effect of cardiopulmonary bypass on urea cycle intermediates and nitric oxide levels after congenital heart surgery. J Pediatr 2003;142(1):26-30.

133. McCaffrey MJ, Bose CL, Reiter PD, Stiles AD. Effect of L-arginine infusion on infants with persistent pulmonary hypertension of the newborn. Biol Neonate 1995;67(4):240-243.

134. Morris CR, Morris SM Jr, Hagar W, Van Warmerdam J, Claster S, Kepka-Lenhart D, et al. Arginine therapy: a new treatment for pulmonary hypertension in sickle cell disease? Am J Respir Crit Care Med 2003;168(1):63-69.

135. Schulze-Neick I, Penny DJ, Rigby ML, Morgan C, Kelleher A, Collins $\mathrm{P}$, et al. L-arginine and substance $\mathrm{P}$ reverse the pulmonary endothelial dysfunction caused by congenital heart surgery. Circulation 1999;100(7):749-755.

136. Smith HA, Canter JA, Christian KG, Drinkwater DC, Scholl FG, Christman BW, et al. Nitric oxide precursors and congenital heart surgery: a randomized controlled trial of oral citrulline. J Thorac Cardiovasc Surg 2006;132(1):58-65.

137. Schermuly RT, Stasch JP, Pullamsetti SS, Middendorff R, Muller $\mathrm{D}$, Schluter KD, et al. Expression and function of soluble guanylate cyclase in pulmonary arterial hypertension. Eur Respir J 2008; 32(4):881-891.

138. Dumitrascu R, Weissmann N, Ghofrani HA, Dony E, Beuerlein K, Schmidt $\mathrm{H}$, et al. Activation of soluble guanylate cyclase reverses experimental pulmonary hypertension and vascular remodeling. Circulation 2006;113(2):286-295.

139. Pankey EA, Bhartiya M, Badejo AM Jr, Haider U, Stasch JP, Murthy SN, et al. Pulmonary and Systemic Vasodilator Responses 


\section{Advances in the Management of Pediatric Pulmonary Hypertension}

to the Soluble Guanylyl Cyclase Activator,Bay 60-2770, Are Not Dependent On Endogenous Nitric Oxide or Reduced Heme. Am J Physiol Heart Circ Physiol 2011.

140. Grimminger F, Weimann G, Frey R, Voswinckel R, Thamm M, Bolkow D, et al. First acute haemodynamic study of soluble guanylate cyclase stimulator riociguat in pulmonary hypertension. Eur Respir J 2009;33(4):785-792.

141. Mittendorf J, Weigand S, Alonso-Alija C, Bischoff E, Feurer A, Gerisch M, et al. Discovery of riociguat (BAY 63-2521): a potent, oral stimulator of soluble guanylate cyclase for the treatment of pulmonary hypertension. ChemMedChem 2009;4(5):853-865.

142. Ghofrani HA, Hoeper MM, Halank M, Meyer FJ, Staehler G, Behr $\mathrm{J}$, et al. Riociguat for chronic thromboembolic pulmonary hypertension and pulmonary arterial hypertension: a phase II study. Eur Respir J 2010;36(4):792-799.

143. Braughler JM, Mittal CK, Murad F. Effects of thiols, sugars, and proteins on nitric oxide activation of guanylate cyclase. J Biol Chem 1979;254(24):12450-12454.

144. Schmidt HH, Schmidt PM, Stasch JP. NO- and haem-independent soluble guanylate cyclase activators. Handb Exp Pharmacol 2009; (191):309-339.

145. Higenbottam T, Wheeldon D, Wells F, Wallwork J. Long-term treatment of primary pulmonary hypertension with continuous intravenous epoprostenol (prostacyclin). Lancet 1984;1(8385):1046-1047.

146. Barst RJ, Rubin LJ, Long WA, McGoon MD, Rich S, Badesch DB, et al. A comparison of continuous intravenous epoprostenol (prostacyclin) with conventional therapy for primary pulmonary hypertension. The Primary Pulmonary Hypertension Study Group. N Engl J Med 1996;334(5):296-302.

147. Sitbon O, Humbert M, Nunes H, Parent F, Garcia G, Herve P, et al. Long-term intravenous epoprostenol infusion in primary pulmonary hypertension: prognostic factors and survival. J Am Coll Cardiol 2002;40(4):780-788.

148. McLaughlin VV, Genthner DE, Panella MM, Rich S. Reduction in pulmonary vascular resistance with long-term epoprostenol (prostacyclin) therapy in primary pulmonary hypertension. N Engl J Med 1998;338(5):273-277.

149. Yung D, Widlitz AC, Rosenzweig EB, Kerstein D, Maislin G, Barst RJ. Outcomes in children with idiopathic pulmonary arterial hypertension. Circulation 2004;110(6):660-665.

150. D’Alonzo GE, Barst RJ, Ayres SM, Bergofsky EH, Brundage BH, Detre KM, et al. Survival in patients with primary pulmonary hypertension. Results from a national prospective registry. Ann Intern Med 1991;115(5):343-349.

151. Tapson VF, Gomberg-Maitland M, McLaughlin VV, Benza RL, Widlitz AC, Krichman A, et al. Safety and efficacy of IV treprostinil for pulmonary arterial hypertension: a prospective, multicenter, open-label, 12-week trial. Chest 2006;129(3):683-688.

152. Ivy DD, Claussen L, Doran A. Transition of stable pediatric patients with pulmonary arterial hypertension from intravenous epoprostenol to intravenous treprostinil. Am J Cardiol 2007;99(5):696-698.

153. Rosenzweig EB, Kerstein D, Barst RJ. Long-term prostacyclin for pulmonary hypertension with associated congenital heart defects. Circulation 1999;99(14):1858-1865.

154. Katz SL, Adatia I, Louca E, Leung K, Humpl T, Reyes JT, et al. Nebulized therapies for childhood pulmonary hypertension: an in vitro model. Pediatr Pulmonol 2006;41(7):666-673.

155. Kelly LK, Porta NF, Goodman DM, Carroll CL, Steinhorn RH. Inhaled prostacyclin for term infants with persistent pulmonary hypertension refractory to inhaled nitric oxide. J Pediatr 2002; 141(6):830-832.

156. Hoeper MM, Schwarze M, Ehlerding S, Adler-Schuermeyer A, Spiekerkoetter E, Niedermeyer J, et al. Long-term treatment of primary pulmonary hypertension with aerosolized iloprost, a prostacyclin analogue. N Engl J Med 2000;342(25):1866-1870.

157. Ivy DD, Doran AK, Smith KJ, Mallory GB Jr, Beghetti M, Barst RJ, et al. Short- and long-term effects of inhaled iloprost therapy in children with pulmonary arterial hypertension. J Am Coll Cardiol 2008;51(2):161-169.

158. Rimensberger PC, Spahr-Schopfer I, Berner M, Jaeggi E, Kalangos A, Friedli B, et al. Inhaled nitric oxide versus aerosolized iloprost in secondary pulmonary hypertension in children with congenital heart disease: vasodilator capacity and cellular mechanisms. Circulation 2001;103(4):544-548.

159. Limsuwan A, Wanitkul S, Khosithset A, Attanavanich S, Samankatiwat P. Aerosolized iloprost for postoperative pulmonary hypertensive crisis in children with congenital heart disease. Int J Cardiol 2008;129(3):333-338.

160. Channick RN, Olschewski H, Seeger W, Staub T, Voswinckel R, Rubin LJ. Safety and efficacy of inhaled treprostinil as add-on therapy to bosentan in pulmonary arterial hypertension. J Am Coll Cardiol 2006;48(7):1433-1437.

161. Voswinckel R, Enke B, Reichenberger F, Kohstall M, Kreckel A, Krick S, et al. Favorable effects of inhaled treprostinil in severe pulmonary hypertension: results from randomized controlled pilot studies. J Am Coll Cardiol 2006;48(8):1672-1681.

162. Voswinckel R, Reichenberger F, Enke B, Kreckel A, Krick S, Gall $\mathrm{H}$, et al. Acute effects of the combination of sildenafil and inhaled treprostinil on haemodynamics and gas exchange in pulmonary hypertension. Pulm Pharmacol Ther 2008;21(5):824-832.

163. McLaughlin VV, Benza RL, Rubin LJ, Channick RN, Voswinckel R, Tapson VF, et al. Addition of inhaled treprostinil to oral therapy for pulmonary arterial hypertension: a randomized controlled clinical trial. J Am Coll Cardiol 2010;55(18):1915-1922.

164. Simonneau G, Barst RJ, Galie N, Naeije R, Rich S, Bourge RC, et al. Continuous subcutaneous infusion of treprostinil, a prostacyclin analogue, in patients with pulmonary arterial hypertension: a double-blind, randomized, placebo-controlled trial. Am J Respir Crit Care Med 2002;165(6):800-804.

165. Barst RJ, Galie N, Naeije R, Simonneau G, Jeffs R, Arneson C, et al. Long-term outcome in pulmonary arterial hypertension patients treated with subcutaneous treprostinil. Eur Respir J 2006;28(6): 1195-1203.

166. Lang I, Gomez-Sanchez M, Kneussl M, Naeije R, Escribano P, Skoro-Sajer N, et al. Efficacy of long-term subcutaneous treprostinil sodium therapy in pulmonary hypertension. Chest 2006;129(6): 1636-1643.

167. Gomberg-Maitland M, Tapson VF, Benza RL, McLaughlin VV, Krichman A, Widlitz AC, et al. Transition from intravenous epoprostenol to intravenous treprostinil in pulmonary hypertension. Am J Respir Crit Care Med 2005;172(12):1586-1589.

168. Oudiz RJ, Schilz RJ, Barst RJ, Galie N, Rich S, Rubin LJ, et al. Treprostinil, a prostacyclin analogue, in pulmonary arterial hypertension associated with connective tissue disease. Chest 2004;126(2): 420-427.

169. McLaughlin VV, Gaine SP, Barst RJ, Oudiz RJ, Bourge RC, Frost A, et al. Efficacy and safety of treprostinil: an epoprostenol analog for primary pulmonary hypertension. J Cardiovasc Pharmacol 2003; 41(2):293-299.

170. Levy M, Celermajer DS, Bourges-Petit E, Del Cerro MJ, Bajolle F, Bonnet D. Add-On Therapy with Subcutaneous Treprostinil for Refractory Pediatric Pulmonary Hypertension. J Pediatr 2010.

171. Ivy DD, Rosenzweig EB, Lemarie JC, Brand M, Rosenberg D, Barst RJ. Long-term outcomes in children with pulmonary arterial hypertension treated with bosentan in real-world clinical settings. Am J Cardiol 2010;106(9):1332-1338. 


\section{Advances in the Management of Pediatric Pulmonary Hypertension}

172. Barst RJ, McGoon M, McLaughlin V, Tapson V, Rich S, Rubin L, et al. Beraprost therapy for pulmonary arterial hypertension. J Am Coll Cardiol 2003;41(12):2119-2125.

173. Galie N, Humbert M, Vachiery JL, Vizza CD, Kneussl M, Manes A, et al. Effects of beraprost sodium, an oral prostacyclin analogue, in patients with pulmonary arterial hypertension: a randomized, double-blind, placebo-controlled trial. J Am Coll Cardiol 2002; 39(9):1496-1502.

174. Kunieda T, Nakanishi N, Matsubara H, Ohe T, Okano Y, Kondo H, et al. Effects of long-acting beraprost sodium (TRK-100STP) in Japanese patients with pulmonary arterial hypertension. Int Heart J 2009;50(4):513-529.

175. Schulze-Neick I, Li J, Reader JA, Shekerdemian L, Redington AN, Penny DJ. The endothelin antagonist BQ123 reduces pulmonary vascular resistance after surgical intervention for congenital heart disease. J Thorac Cardiovasc Surg 2002;124(3):435-441.

176. Channick RN, Simonneau G, Sitbon O, Robbins IM, Frost A, Tapson VF, et al. Effects of the dual endothelin-receptor antagonist bosentan in patients with pulmonary hypertension: a randomised placebo-controlled study. Lancet 2001;358(9288):1119-1123.

177. Rubin LJ, Badesch DB, Barst RJ, Galie N, Black CM, Keogh A, et al. Bosentan therapy for pulmonary arterial hypertension. N Engl J Med 2002;346(12):896-903.

178. Galie N, Beghetti M, Gatzoulis MA, Granton J, Berger RM, Lauer A, et al. Bosentan therapy in patients with Eisenmenger syndrome: a multicenter, double-blind, randomized, placebo-controlled study. Circulation 2006;114(1):48-54.

179. Maiya S, Hislop AA, Flynn Y, Haworth SG. Response to bosentan in children with pulmonary hypertension. Heart 2006;92(5):664670.

180. Black SM, Mata-Greenwood E, Dettman RW, Ovadia B, Fitzgerald RK, Reinhartz O, et al. Emergence of smooth muscle cell endothelin B-mediated vasoconstriction in lambs with experimental congenital heart disease and increased pulmonary blood flow. Circulation 2003;108(13):1646-1654.

181. Bauer M, Wilkens H, Langer F, Schneider SO, Lausberg H, Schafers HJ. Selective upregulation of endothelin B receptor gene expression in severe pulmonary hypertension. Circulation 2002;105(9): 1034-1036.

182. Benza RL, Barst RJ, Galie N, Frost A, Girgis RE, Highland KB, et al. Sitaxsentan for the treatment of pulmonary arterial hypertension: a 1-year, prospective, open-label observation of outcome and survival. Chest 2008;134(4):775-782.

183. Barst RJ, Langleben D, Badesch D, Frost A, Lawrence EC, Shapiro $\mathrm{S}$, et al. Treatment of pulmonary arterial hypertension with the selective endothelin-A receptor antagonist sitaxsentan. J Am Coll Cardiol 2006;47(10):2049-2056.

184. Barst RJ, Langleben D, Frost A, Horn EM, Oudiz R, Shapiro S, et al. Sitaxsentan therapy for pulmonary arterial hypertension. Am J Respir Crit Care Med 2004;169(4):441-447.

185. Barst RJ, Rich S, Widlitz A, Horn EM, McLaughlin V, McFarlin J. Clinical efficacy of sitaxsentan, an endothelin-A receptor antagonist, in patients with pulmonary arterial hypertension: open-label pilot study. Chest 2002;121(6):1860-1868.

186. Dingemanse J, van Giersbergen PL. Clinical pharmacology of bosentan, a dual endothelin receptor antagonist. Clin Pharmacokinet 2004; 43(15):1089-1115.

187. Horn EM, Widlitz AC, Barst RJ. Sitaxsentan, a selective endothelin-A receptor antagonist for the treatment of pulmonary arterial hypertension. Expert Opin Investig Drugs 2004;13(11):1483-1492.

188. Spence R, Mandagere A, Dufton C, Venitz J. Pharmacokinetics and safety of ambrisentan in combination with sildenafil in healthy volunteers. J Clin Pharmacol 2008;48(12):1451-1459.
189. McGoon MD, Frost AE, Oudiz RJ, Badesch DB, Galie N, Olschewski $\mathrm{H}$, et al. Ambrisentan therapy in patients with pulmonary arterial hypertension who discontinued bosentan or sitaxsentan due to liver function test abnormalities. Chest 2009;135(1):122-129.

190. Humbert M, Barst RJ, Robbins IM, Channick RN, Galie N, Boonstra A, et al. Combination of bosentan with epoprostenol in pulmonary arterial hypertension: BREATHE-2. Eur Respir J 2004; 24(3):353-359.

191. McLaughlin VV, Oudiz RJ, Frost A, Tapson VF, Murali S, Channick RN, et al. Randomized study of adding inhaled iloprost to existing bosentan in pulmonary arterial hypertension. Am J Respir Crit Care Med 2006;174(11):1257-1263.

192. Hoeper MM, Leuchte H, Halank M, Wilkens H, Meyer FJ, Seyfarth $\mathrm{HJ}$, et al. Combining inhaled iloprost with bosentan in patients with idiopathic pulmonary arterial hypertension. Eur Respir J 2006;28(4): 691-694.

193. Simonneau G, Rubin LJ, Galie N, Barst RJ, Fleming TR, Frost AE, et al. Addition of sildenafil to long-term intravenous epoprostenol therapy in patients with pulmonary arterial hypertension: a randomized trial. Ann Intern Med 2008;149(8):521-530.

194. Ghofrani HA, Rose F, Schermuly RT, Olschewski H, Wiedemann $\mathrm{R}$, Kreckel A, et al. Oral sildenafil as long-term adjunct therapy to inhaled iloprost in severe pulmonary arterial hypertension. J Am Coll Cardiol 2003;42(1):158-164.

195. Galie N, Rubin L, Hoeper M, Jansa P, Al-Hiti H, Meyer G, et al. Treatment of patients with mildly symptomatic pulmonary arterial hypertension with bosentan (EARLY study): a double-blind, randomised controlled trial. Lancet 2008;371(9630):2093-2100.

196. Black SM, Ross PA, Levic S, Hallmark O. Reactive oxygen species inhibit endothelial NOS by mutiple mechanisms (abstract). Pediatr Res 1999;44:A1742.

197. Kalinowski L, Dobrucki IT, Malinski T. Cicletanine stimulates nitric oxide release and scavenges superoxide in endothelial cells. J Cardiovasc Pharmacol 2001;37(6):713-724.

198. Saadjian A, Philip-Joet F, Paganelli F, Arnaud A, Levy S. Longterm effects of cicletanine on secondary pulmonary hypertension. J Cardiovasc Pharmacol 1998;31(3):364-371.

199. Waxman AB, Lawler L, Cornett G. Cicletanine for the treatment of pulmonary arterial hypertension. Arch Intern Med 2008;168(19): 2164-2166.

200. Cai H, Harrison DG. Endothelial dysfunction in cardiovascular diseases: the role of oxidant stress. Circ Res 2000;87(10):840-844.

201. Garcia CE, Kilcoyne CM, Cardillo C, Cannon RO, 3rd, Quyyumi AA, Panza JA. Effect of copper-zinc superoxide dismutase on endothelium-dependent vasodilation in patients with essential hypertension. Hypertension 1995;26(6 Pt 1):863-868.

202. Rosenfeld WN, Davis JM, Parton L, Richter SE, Price A, Flaster E, et al. Safety and pharmacokinetics of recombinant human superoxide dismutase administered intratracheally to premature neonates with respiratory distress syndrome. Pediatrics 1996;97(6 Pt 1):811817.

203. Davis JM, Rosenfeld WN, Richter SE, Parad MR, Gewolb IH, Spitzer AR, et al. Safety and pharmacokinetics of multiple doses of recombinant human CuZn superoxide dismutase administered intratracheally to premature neonates with respiratory distress syndrome. Pediatrics 1997;100(1):24-30.

204. Steinhorn RH, Albert G, Swartz DD, Russell JA, Levine CR, Davis JM. Recombinant human superoxide dismutase enhances the effect of inhaled nitric oxide in persistent pulmonary hypertension. Am J Respir Crit Care Med 2001;164(5):834-839.

205. Asahara T, Murohara T, Sullivan A, Silver M, van der Zee R, Li T, et al. Isolation of putative progenitor endothelial cells for angiogenesis. Science 1997;275(5302):964-967. 


\section{Advances in the Management of Pediatric Pulmonary Hypertension}

206. Baber SR, Deng W, Master RG, Bunnell BA, Taylor BK, Murthy $\mathrm{SN}$, et al. Intratracheal mesenchymal stem cell administration attenuates monocrotaline-induced pulmonary hypertension and endothelial dysfunction. Am J Physiol Heart Circ Physiol 2007;292(2): H1120-H1128.

207. Kanki-Horimoto S, Horimoto H, Mieno S, Kishida K, Watanabe F, Furuya E, et al. Implantation of mesenchymal stem cells overexpressing endothelial nitric oxide synthase improves right ventricular impairments caused by pulmonary hypertension. Circulation 2006;114(1 Suppl):I181-I185.

208. Zhao YD, Courtman DW, Deng Y, Kugathasan L, Zhang Q, Stewart DJ. Rescue of monocrotaline-induced pulmonary arterial hypertension using bone marrow-derived endothelial-like progenitor cells: efficacy of combined cell and eNOS gene therapy in established disease. Circ Res 2005;96(4):442-450.

209. Junhui Z, Xingxiang W, Guosheng F, Yunpeng S, Furong Z, Junzhu C. Reduced number and activity of circulating endothelial progenitor cells in patients with idiopathic pulmonary arterial hypertension. Respir Med 2008;102(7):1073-1079.

210. Diller GP, van Eijl S, Okonko DO, Howard LS, Ali O, Thum T, et al. Circulating endothelial progenitor cells in patients with Eisenmenger syndrome and idiopathic pulmonary arterial hypertension. Circulation 2008;117(23):3020-3030.

211. Wang XX, Zhang FR, Shang YP, Zhu JH, Xie XD, Tao QM, et al. Transplantation of autologous endothelial progenitor cells may be beneficial in patients with idiopathic pulmonary arterial hypertension: a pilot randomized controlled trial. J Am Coll Cardiol 2007; 49(14):1566-1571.

212. Zhu JH, Wang XX, Zhang FR, Shang YP, Tao QM, Chen JZ. Safety and efficacy of autologous endothelial progenitor cells transplantation in children with idiopathic pulmonary arterial hypertension: open-label pilot study. Pediatr Transplant 2008;12(6):650655 .

213. Smadja DM, Mauge L, Gaussem P, d'Audigier C, Israel-Biet D, Celermajer DS, et al. Treprostinil increases the number and angiogenic potential of endothelial progenitor cells in children with pulmonary hypertension. Angiogenesis 2010.

214. Said SI, Hamidi SA, Dickman KG, Szema AM, Lyubsky S, Lin RZ, et al. Moderate pulmonary arterial hypertension in male mice lacking the vasoactive intestinal peptide gene. Circulation 2007;115(10): 1260-1268.

215. Petkov V, Mosgoeller W, Ziesche R, Raderer M, Stiebellehner L, Vonbank K, et al. Vasoactive intestinal peptide as a new drug for treatment of primary pulmonary hypertension. J Clin Invest 2003; 111(9):1339-1346.

216. Murakami S, Kimura H, Kangawa K, Nagaya N. Physiological significance and therapeutic potential of adrenomedullin in pulmonary hypertension. Cardiovasc Hematol Disord Drug Targets 2006; 6(2):125-132.

217. Kakishita M, Nishikimi T, Okano Y, Satoh T, Kyotani S, Nagaya $\mathrm{N}$, et al. Increased plasma levels of adrenomedullin in patients with pulmonary hypertension. Clin Sci (Lond) 1999;96(1):33-39.

218. Nagaya N, Kyotani S, Uematsu M, Ueno K, Oya H, Nakanishi N, et al. Effects of adrenomedullin inhalation on hemodynamics and exercise capacity in patients with idiopathic pulmonary arterial hypertension. Circulation 2004;109(3):351-356.

219. Fuster V, Steele PM, Edwards WD, Gersh BJ, McGoon MD, Frye RL. Primary pulmonary hypertension: natural history and the importance of thrombosis. Circulation 1984;70(4):580-587.

220. Frank H, Mlczoch J, Huber K, Schuster E, Gurtner HP, Kneussl M. The effect of anticoagulant therapy in primary and anorectic druginduced pulmonary hypertension. Chest 1997;112(3):714-721.
221. Rich S, Kaufmann E, Levy PS. The effect of high doses of calciumchannel blockers on survival in primary pulmonary hypertension. N Engl J Med 1992;327(2):76-81.

222. Montani D, Savale L, Natali D, Jais X, Herve P, Garcia G, et al. Long-term response to calcium-channel blockers in non-idiopathic pulmonary arterial hypertension. Eur Heart J 2010;31(15):18981907.

223. Guilluy C, Eddahibi S, Agard C, Guignabert C, Izikki M, Tu L, et al. RhoA and Rho kinase activation in human pulmonary hypertension: role of 5-HT signaling. Am J Respir Crit Care Med 2009; 179(12):1151-1158

224. Oka M, Homma N, Taraseviciene-Stewart L, Morris KG, Kraskauskas D, Burns N, et al. Rho kinase-mediated vasoconstriction is important in severe occlusive pulmonary arterial hypertension in rats. Circ Res 2007;100(6):923-929.

225. McNamara PJ, Murthy P, Kantores C, Teixeira L, Engelberts D, van Vliet T, et al. Acute vasodilator effects of Rho-kinase inhibitors in neonatal rats with pulmonary hypertension unresponsive to nitric oxide. Am J Physiol Lung Cell Mol Physiol 2008;294(2):L205L213.

226. Fujita H, Fukumoto Y, Saji K, Sugimura K, Demachi J, Nawata J, et al. Acute vasodilator effects of inhaled fasudil, a specific Rhokinase inhibitor, in patients with pulmonary arterial hypertension. Heart Vessels 2010;25(2):144-149.

227. Li F, Xia W, Yuan S, Sun R. Acute inhibition of Rho-kinase attenuates pulmonary hypertension in patients with congenital heart disease. Pediatr Cardiol 2009;30(3):363-366.

228. Ishikura K, Yamada N, Ito M, Ota S, Nakamura M, Isaka N, et al. Beneficial acute effects of rho-kinase inhibitor in patients with pulmonary arterial hypertension. Circ J 2006;70(2):174-178.

229. Fukumoto Y, Matoba T, Ito A, Tanaka H, Kishi T, Hayashidani S, et al. Acute vasodilator effects of a Rho-kinase inhibitor, fasudil, in patients with severe pulmonary hypertension. Heart 2005;91(3): 391-392.

230. Nagendran J, Sutendra G, Haromy A, Fu DZ, Ross DB, Rebeyka IM, et al. Endothelin receptor inhibitors decrease contractility in the hypertrophied right ventricle (abstract). Am J Respir Crit Care Med 2007;179:A4141.

231. Yerebakan C, Klopsch C, Niefeldt S, Zeisig V, Vollmar B, Liebold $\mathrm{A}$, et al. Acute and chronic response of the right ventricle to surgically induced pressure and volume overload: an analysis of pressure-volume relations. Interact Cardiovasc Thorac Surg 2010;10(4): 519-525.

232. de Vroomen M, Cardozo RH, Steendijk P, van Bel F, Baan J. Improved contractile performance of right ventricle in response to increased RV afterload in newborn lamb. Am J Physiol Heart Circ Physiol 2000;278(1):H100-H105.

233. Hopkins WE, Waggoner AD. Severe pulmonary hypertension without right ventricular failure: the unique hearts of patients with Eisenmenger syndrome. Am J Cardiol 2002;89(1):34-38.

234. Watts JA, Marchick MR, Kline JA. Right ventricular heart failure from pulmonary embolism: key distinctions from chronic pulmonary hypertension. J Card Fail 2010;16(3):250-259.

235. Belenkie I, Dani R, Smith ER, Tyberg JV. Ventricular interaction during experimental acute pulmonary embolism. Circulation 1988; 78(3):761-768.

236. Gan CT, Lankhaar JW, Marcus JT, Westerhof N, Marques KM, Bronzwaer JG, et al. Impaired left ventricular filling due to rightto-left ventricular interaction in patients with pulmonary arterial hypertension. Am J Physiol Heart Circ Physiol 2006;290(4):H15281533.

237. Belenkie I, Horne SG, Dani R, Smith ER, Tyberg JV. Effects of aortic constriction during experimental acute right ventricular pres- 


\section{Advances in the Management of Pediatric Pulmonary Hypertension}

sure loading. Further insights into diastolic and systolic ventricular interaction. Circulation 1995;92(3):546-554.

238. Yamaguchi S, Harasawa H, Li KS, Zhu D, Santamore WP. Comparative significance in systolic ventricular interaction. Cardiovasc Res 1991;25(9):774-783.

239. Santamore WP, Dell'Italia LJ. Ventricular interdependence: significant left ventricular contributions to right ventricular systolic function. Prog Cardiovasc Dis 1998;40(4):289-308.

240. Chockalingam A, Mehra A, Dorairajan S, Dellsperger KC. Acute left ventricular dysfunction in the critically ill. Chest 2010;138(1): 198-207.

241. Lepore JJ, Maroo A, Bigatello LM, Dec GW, Zapol WM, Bloch $\mathrm{KD}$, et al. Hemodynamic effects of sildenafil in patients with congestive heart failure and pulmonary hypertension: combined administration with inhaled nitric oxide. Chest 2005;127(5):1647-1653.

242. Lewis GD, Shah R, Shahzad K, Camuso JM, Pappagianopoulos PP, Hung J, et al. Sildenafil improves exercise capacity and quality of life in patients with systolic heart failure and secondary pulmonary hypertension. Circulation 2007;116(14):1555-1562.

243. Mathru M, Venus B, Smith RA, Shirakawa Y, Sugiura A. Treatment of low cardiac output complicating acute pulmonary hypertension in normovolemic goats. Crit Care Med 1986;14(2):120-124.

244. Molloy WD, Lee KY, Girling L, Schick U, Prewitt RM. Treatment of shock in a canine model of pulmonary embolism. Am Rev Respir Dis 1984;130(5):870-874.

245. Ghignone M, Girling L, Prewitt RM. Volume expansion versus norepinephrine in treatment of a low cardiac output complicating an acute increase in right ventricular afterload in dogs. Anesthesiology 1984;60(2):132-135.

246. Belenkie I, Dani R, Smith ER, Tyberg JV. Effects of volume loading during experimental acute pulmonary embolism. Circulation 1989;80(1):178-188.

247. Mercat A, Diehl JL, Meyer G, Teboul JL, Sors H. Hemodynamic effects of fluid loading in acute massive pulmonary embolism. Crit Care Med 1999;27(3):540-544.

248. Siva A, Shah AM. Moderate mitral stenosis in pregnancy: the haemodynamic impact of diuresis. Heart 2005;91(1):e3.

249. Ducas J, Prewitt RM. Pathophysiology and therapy of right ventricular dysfunction due to pulmonary embolism. Cardiovasc Clin 1987;17(2):191-202.

250. Holloway EL, Polumbo RA, Harrison DC. Acute circulatory effects of dopamine in patients with pulmonary hypertension. Br Heart $\mathrm{J}$ 1975;37(5):482-485.

251. Liet JM, Boscher C, Gras-Leguen C, Gournay V, Debillon T, Roze JC. Dopamine effects on pulmonary artery pressure in hypotensive preterm infants with patent ductus arteriosus. J Pediatr 2002;140(3): 373-375.

252. Barrington KJ, Finer NN, Chan WK. A blind, randomized comparison of the circulatory effects of dopamine and epinephrine infusions in the newborn piglet during normoxia and hypoxia. Crit Care Med 1995;23(4):740-748.

253. Leier CV, Heban PT, Huss P, Bush CA, Lewis RP. Comparative systemic and regional hemodynamic effects of dopamine and dobutamine in patients with cardiomyopathic heart failure. Circulation 1978;58(3 Pt 1):466-475

254. Acosta F, Sansano T, Palenciano CG, Falcon L, Domenech P, Robles R, et al. Effects of dobutamine on right ventricular function and pulmonary circulation in pulmonary hypertension during liver transplantation. Transplant Proc 2005;37(9):3869-3870.

255. Ferrario M, Poli A, Previtali M, Lanzarini L, Fetiveau R, Diotallevi $\mathrm{P}$, et al. Hemodynamics of volume loading compared with dobutamine in severe right ventricular infarction. Am J Cardiol 1994; 74(4):329-333
256. Kihara S, Kawai A, Fukuda T, Yamamoto N, Aomi S, Nishida H, et al. Effects of milrinone for right ventricular failure after left ventricular assist device implantation. Heart Vessels 2002;16(2): 69-71.

257. Fukazawa K, Poliac LC, Pretto EA. Rapid assessment and safe management of severe pulmonary hypertension with milrinone during orthotopic liver transplantation. Clin Transplant 2010;24(4): 515-519.

258. Eichhorn EJ, Konstam MA, Weiland DS, Roberts DJ, Martin TT, Stransky NB, et al. Differential effects of milrinone and dobutamine on right ventricular preload, afterload and systolic performance in congestive heart failure secondary to ischemic or idiopathic dilated cardiomyopathy. Am J Cardiol 1987;60(16):13291333.

259. Slawsky MT, Colucci WS, Gottlieb SS, Greenberg BH, Haeusslein E, Hare J, et al. Acute hemodynamic and clinical effects of levosimendan in patients with severe heart failure. Study Investigators. Circulation 2000;102(18):2222-2227.

260. Russ MA, Prondzinsky R, Carter JM, Schlitt A, Ebelt H, Schmidt $\mathrm{H}$, et al. Right ventricular function in myocardial infarction complicated by cardiogenic shock: improvement with levosimendan. Crit Care Med 2009;37(12):3017-3023.

261. Poelzl G, Zwick RH, Grander W, Metzler B, Jonetzko P, Frick M, et al. Safety and effectiveness of levosimendan in patients with predominant right heart failure. Herz 2008;33(5):368-373.

262. Cicekcioglu F, Parlar AI, Ersoy O, Yay K, Hijazi A, Katircioglu SF. Levosimendan and severe pulmonary hypertension during open heart surgery. Gen Thorac Cardiovasc Surg 2008;56(11):563-565.

263. Kleber FX, Bollmann T, Borst MM, Costard-Jackle A, Ewert R, Kivikko M, et al. Repetitive dosing of intravenous levosimendan improves pulmonary hemodynamics in patients with pulmonary hypertension: results of a pilot study. J Clin Pharmacol 2009;49(1): 109-115.

264. Kerbaul F, Rondelet B, Motte S, Fesler P, Hubloue I, Ewalenko P, et al. Effects of norepinephrine and dobutamine on pressure loadinduced right ventricular failure. Crit Care Med 2004;32(4):10351040.

265. Hirsch LJ, Rooney MW, Wat SS, Kleinmann B, Mathru M. Norepinephrine and phenylephrine effects on right ventricular function in experimental canine pulmonary embolism. Chest 1991;100(3): 796-801.

266. Tourneux P, Rakza T, Bouissou A, Krim G, Storme L. Pulmonary circulatory effects of norepinephrine in newborn infants with persistent pulmonary hypertension. J Pediatr 2008;153(3):345-349.

267. Kwak YL, Lee CS, Park YH, Hong YW. The effect of phenylephrine and norepinephrine in patients with chronic pulmonary hypertension*. Anaesthesia 2002;57(1):9-14.

268. Vlahakes GJ, Turley K, Hoffman JI. The pathophysiology of failure in acute right ventricular hypertension: hemodynamic and biochemical correlations. Circulation 1981;63(1):87-95.

269. Tayama E, Ueda T, Shojima T, Akasu K, Oda T, Fukunaga S, et al. Arginine vasopressin is an ideal drug after cardiac surgery for the management of low systemic vascular resistant hypotension concomitant with pulmonary hypertension. Interact Cardiovasc Thorac Surg 2007;6(6):715-719.

270. Jeon Y, Ryu JH, Lim YJ, Kim CS, Bahk JH, Yoon SZ, et al. Comparative hemodynamic effects of vasopressin and norepinephrine after milrinone-induced hypotension in off-pump coronary artery bypass surgical patients. Eur J Cardiothorac Surg 2006;29(6): 952-956.

271. Smith AM, Elliot CM, Kiely DG, Channer KS. The role of vasopressin in cardiorespiratory arrest and pulmonary hypertension. QJM 2006;99(3):127-133. 


\section{Advances in the Management of Pediatric Pulmonary Hypertension}

272. Russell JA, Walley KR, Singer J, Gordon AC, Hebert PC, Cooper DJ, et al. Vasopressin versus norepinephrine infusion in patients with septic shock. N Engl J Med 2008;358(9):877-887.

273. Walker BR, Haynes J Jr, Wang HL, Voelkel NF. Vasopressininduced pulmonary vasodilation in rats. Am J Physiol 1989;257(2 Pt 2):H415-422.

274. Eichinger MR, Walker BR. Enhanced pulmonary arterial dilation to arginine vasopressin in chronically hypoxic rats. Am J Physiol 1994;267(6 Pt 2):H2413-2419.

275. Rich S, Lam W. Atrial septostomy as palliative therapy for refractory primary pulmonary hypertension. Am J Cardiol 1983;51(9): $1560-1561$.

276. Mullins CE, Nihill MR, Vick GW, 3rd, Ludomirsky A, O’Laughlin MP, Bricker JT, et al. Double balloon technique for dilation of valvular or vessel stenosis in congenital and acquired heart disease. J Am Coll Cardiol 1987;10(1):107-114.

277. Hausknecht MJ, Sims RE, Nihill MR, Cashion WR. Successful palliation of primary pulmonary hypertension by atrial septostomy. Am J Cardiol 1990;65(15):1045-1046.

278. Kerstein D, Levy PS, Hsu DT, Hordof AJ, Gersony WM, Barst RJ. Blade balloon atrial septostomy in patients with severe primary pulmonary hypertension. Circulation 1995;91(7):2028-2035.

279. Sandoval J, Gaspar J, Pulido T, Bautista E, Martinez-Guerra ML, Zeballos M, et al. Graded balloon dilation atrial septostomy in severe primary pulmonary hypertension. A therapeutic alternative for patients nonresponsive to vasodilator treatment. J Am Coll Cardiol 1998;32(2):297-304.

280. Barst RJ. Role of atrial septostomy in the treatment of pulmonary vascular disease. Thorax 2000;55(2):95-96.

281. Labombarda F, Maragnes P, Dupont-Chauvet P, Serraf A. Potts anastomosis for children with idiopathic pulmonary hypertension. Pediatr Cardiol 2009;30(8):1143-1145.

282. Hoffman JI. Natural history of congenital heart disease. Problems in its assessment with special reference to ventricular septal defects. Circulation 1968;37(1):97-125.

283. Hanley FL, Heinemann MK, Jonas RA, Mayer JE Jr, Cook NR, Wessel DL, et al. Repair of truncus arteriosus in the neonate. J Thorac Cardiovasc Surg 1993;105(6):1047-1056.

284. Kolosionek E, Crosby A, Harhay MO, Morrell N, Butrous G. Pulmonary vascular disease associated with schistosomiasis. Expert Rev Anti Infect Ther 2010;8(12):1467-1473.

285. Cicalini S, Almodovar S, Grilli E, Flores S. Pulmonary hypertension and human immunodeficiency virus infection: epidemiology, pathogenesis, and clinical approach. Clin Microbiol Infect 2011; 17(1):25-33

286. Bandara M, Gordon FD, Sarwar A, Knauft ME, Pomfret EA, Freeman RB, et al. Successful outcomes following living donor liver transplantation for portopulmonary hypertension. Liver Transpl 2010;16(8):983-989.

287. Saleemi S. Portopulmonary hypertension. Ann Thorac Med 2010; 5(1):5-9.

288. Traynor AE, Corbridge TC, Eagan AE, Barr WG, Liu Q, Oyama Y, et al. Prevalence and reversibility of pulmonary dysfunction in refractory systemic lupus: improvement correlates with disease remission following hematopoietic stem cell transplantation. Chest 2005;127(5):1680-1689.

289. Kamata Y, Nara H, Sato H, Masuyama JI, Minota S, Yoshio T. Effect of steroid pulse therapy on mixed connective tissue disease with pulmonary arterial hypertension. Ann Rheum Dis 2005;64(8): 1236-1237.

290. Jouve P, Humbert M, Chauveheid MP, Jais X, Papo T. POEMS syndrome-related pulmonary hypertension is steroid-responsive. Respir Med 2007;101(2):353-355.
291. Benyounes B, Crestani B, Couvelard A, Vissuzaine C, Aubier M. Steroid-responsive pulmonary hypertension in a patient with Langerhans' cell granulomatosis (histiocytosis X). Chest 1996;110(1): 284-286.

292. Rodman DM, Lindenfeld J. Successful treatment of sarcoidosisassociated pulmonary hypertension with corticosteroids. Chest 1990; 97(2):500-502.

293. Adatia I, Shekerdemian L. The role of calcium channel blockers, steroids, anticoagulation, antiplatelet drugs, and endothelin receptor antagonists. Pediatr Crit Care Med 2010;11(2 Suppl):S46-S52.

294. Rees DC, Williams TN, Gladwin MT. Sickle-cell disease. Lancet 2010;376(9757):2018-2031.

295. Konduri GG, Kim UO. Advances in the diagnosis and management of persistent pulmonary hypertension of the newborn. Pediatr Clin North Am 2009;56(3):579-600, Table of Contents.

296. Gozal D, Kheirandish-Gozal L, Serpero LD, Sans Capdevila O, Dayyat E. Obstructive sleep apnea and endothelial function in schoolaged nonobese children: effect of adenotonsillectomy. Circulation 2007;116(20):2307-2314.

297. Yilmaz MD, Onrat E, Altuntas A, Kaya D, Kahveci OK, Ozel O, et al. The effects of tonsillectomy and adenoidectomy on pulmonary arterial pressure in children. Am J Otolaryngol 2005;26(1):18-21.

298. Mucklow ES. Obstructive sleep apnoea causing severe pulmonary hypertension reversed by emergency tonsillectomy. Br J Clin Pract 1989;43(7):260-263.

299. Penaloza D, Arias-Stella J. The heart and pulmonary circulation at high altitudes: healthy highlanders and chronic mountain sickness. Circulation 2007;115(9):1132-1146.

300. Munhoz AS, Adde FV, Nakaie CM, Doria Filho U, Silva Filho LV, Rodrigues JC. Long-term home oxygen therapy in children and adolescents: analysis of clinical use and costs of a home care program. J Pediatr (Rio J) 2011;87(1):13-18.

301. Ohashi N, Matsushima M, Maeda M, Yamaki S. Advantages of oxygen inhalation therapy for postoperative pulmonary hypertension. Pediatr Cardiol 2005;26(1):90-92.

302. Marvisi M, Zambrelli P, Brianti M, Civardi G, Lampugnani R, Delsignore R. Pulmonary hypertension is frequent in hyperthyroidism and normalizes after therapy. Eur J Intern Med 2006;17(4): 267-271.

303. Ghofrani HA, Morrell NW, Hoeper MM, Olschewski H, Peacock $\mathrm{AJ}$, Barst RJ, et al. Imatinib in pulmonary arterial hypertension patients with inadequate response to established therapy. Am J Respir Crit Care Med 2010;182(9):1171-1177.

304. Wilhelm S, Carter C, Lynch M, Lowinger T, Dumas J, Smith RA, et al. Discovery and development of sorafenib: a multikinase inhibitor for treating cancer. Nat Rev Drug Discov 2006;5(10):835844.

305. Klein M, Schermuly RT, Ellinghaus P, Milting H, Riedl B, Nikolova $\mathrm{S}$, et al. Combined tyrosine and serine/threonine kinase inhibition by sorafenib prevents progression of experimental pulmonary hypertension and myocardial remodeling. Circulation 2008;118(20): 2081-2090.

306. Altieri DC. Survivin and IAP proteins in cell-death mechanisms. Biochem J 2010;430(2):199-205.

307. McMurtry MS, Archer SL, Altieri DC, Bonnet S, Haromy A, Harry $\mathrm{G}$, et al. Gene therapy targeting survivin selectively induces pulmonary vascular apoptosis and reverses pulmonary arterial hypertension. J Clin Invest 2005;115(6):1479-1491.

308. Rikitake Y, Liao JK. Rho GTPases, statins, and nitric oxide. Circ Res 2005;97(12):1232-1235.

309. Takemoto M, Sun J, Hiroki J, Shimokawa H, Liao JK. Rho-kinase mediates hypoxia-induced downregulation of endothelial nitric oxide synthase. Circulation 2002;106(1):57-62. 


\section{Advances in the Management of Pediatric Pulmonary Hypertension}

310. Ongini E, Impagnatiello F, Bonazzi A, Guzzetta M, Govoni M, Monopoli A, et al. Nitric oxide (NO)-releasing statin derivatives, a class of drugs showing enhanced antiproliferative and antiinflammatory properties. Proc Natl Acad Sci USA 2004;101(22):8497-8502.

311. Girgis RE, Li D, Zhan X, Garcia JG, Tuder RM, Hassoun PM, et al. Attenuation of chronic hypoxic pulmonary hypertension by simvastatin. Am J Physiol Heart Circ Physiol 2003;285(3):H938-945.

312. Girgis RE, Mozammel S, Champion HC, Li D, Peng X, Shimoda L, et al. Regression of chronic hypoxic pulmonary hypertension by simvastatin. Am J Physiol Lung Cell Mol Physiol 2007;292(5): L1105-L1110.

313. Nishimura T, Vaszar LT, Faul JL, Zhao G, Berry GJ, Shi L, et al. Simvastatin rescues rats from fatal pulmonary hypertension by inducing apoptosis of neointimal smooth muscle cells. Circulation 2003;108(13):1640-1645.

314. Nishimura T, Faul JL, Berry GJ, Vaszar LT, Qiu D, Pearl RG, et al. Simvastatin attenuates smooth muscle neointimal proliferation and pulmonary hypertension in rats. Am J Respir Crit Care Med 2002; 166(10):1403-1408.

315. Taraseviciene-Stewart L, Scerbavicius R, Choe KH, Cool C, Wood $\mathrm{K}$, Tuder RM, et al. Simvastatin causes endothelial cell apoptosis and attenuates severe pulmonary hypertension. Am J Physiol Lung Cell Mol Physiol 2006;291(4):L668-L76.

316. Kao PN. Simvastatin treatment of pulmonary hypertension: an observational case series. Chest 2005;127(4):1446-1452.

317. Lee TM, Chen CC, Shen HN, Chang NC. Effects of pravastatin on functional capacity in patients with chronic obstructive pulmonary disease and pulmonary hypertension. Clin Sci (Lond) 2009;116(6): 497-505.

318. Wilkins MR, Ali O, Bradlow W, Wharton J, Taegtmeyer A, Rhodes $\mathrm{CJ}$, et al. Simvastatin as a treatment for pulmonary hypertension trial. Am J Respir Crit Care Med 2010;181(10):1106-1113.

319. King WT, Day RW. Treatment of pediatric pulmonary hypertension with simvastatin: an observational study. Pediatr Pulmonol 2010.

320. Kersten S, Desvergne B, Wahli W. Roles of PPARs in health and disease. Nature 2000;405(6785):421-424.

321. Ameshima S, Golpon H, Cool CD, Chan D, Vandivier RW, Gardai $\mathrm{SJ}$, et al. Peroxisome proliferator-activated receptor gamma (PPARgamma) expression is decreased in pulmonary hypertension and affects endothelial cell growth. Circ Res 2003;92(10):1162-1169.

322. Falcetti E, Hall SM, Phillips PG, Patel J, Morrell NW, Haworth SG, et al. Smooth muscle proliferation and role of the prostacyclin (IP) receptor in idiopathic pulmonary arterial hypertension. Am J Respir Crit Care Med 2010;182(9):1161-1170.

323. Hansmann G, Wagner RA, Schellong S, Perez VA, Urashima T, Wang L, et al. Pulmonary arterial hypertension is linked to insulin resistance and reversed by peroxisome proliferator-activated receptor-gamma activation. Circulation 2007;115(10):1275-1284.

324. Wakino S, Hayashi K, Tatematsu S, Hasegawa K, Takamatsu I, Kanda T, et al. Pioglitazone lowers systemic asymmetric dimethylarginine by inducing dimethylarginine dimethylaminohydrolase in rats. Hypertens Res 2005;28(3):255-262.

325. Delerive P, Martin-Nizard F, Chinetti G, Trottein F, Fruchart JC, Najib J, et al. Peroxisome proliferator-activated receptor activators inhibit thrombin-induced endothelin-1 production in human vascular endothelial cells by inhibiting the activator protein-1 signaling pathway. Circ Res 1999;85(5):394-402.

326. Subbaramaiah K, Lin DT, Hart JC, Dannenberg AJ. Peroxisome proliferator-activated receptor gamma ligands suppress the transcriptional activation of cyclooxygenase-2. Evidence for involvement of activator protein-1 and CREB-binding protein/p300. J Biol Chem 2001;276(15):12440-12448.

327. Calnek DS, Mazzella L, Roser S, Roman J, Hart CM. Peroxisome proliferator-activated receptor gamma ligands increase release of nitric oxide from endothelial cells. Arterioscler Thromb Vasc Biol 2003;23(1):52-57.

328. Polikandriotis JA, Mazzella LJ, Rupnow HL, Hart CM. Peroxisome proliferator-activated receptor gamma ligands stimulate endothelial nitric oxide production through distinct peroxisome proliferatoractivated receptor gamma-dependent mechanisms. Arterioscler Thromb Vasc Biol 2005;25(9):1810-1816.

329. Hansmann G, de Jesus Perez VA, Alastalo TP, Alvira CM, Guignabert C, Bekker JM, et al. An antiproliferative BMP-2/PPARgamma/ apoE axis in human and murine SMCs and its role in pulmonary hypertension. J Clin Invest 2008;118(5):1846-1857.

330. Hansmann G, Zamanian RT. PPARgamma activation: a potential treatment for pulmonary hypertension. Sci Transl Med 2009;1(12):12ps14.

331. Lu X, Murphy TC, Nanes MS, Hart CM. PPAR \{gamma\} regulates hypoxia-induced Nox4 expression in human pulmonary artery smooth muscle cells through NF-\{kappa\}B. Am J Physiol Lung Cell Mol Physiol 2010;299(4):L559-566.

332. Matsuda Y, Hoshikawa Y, Ameshima S, Suzuki S, Okada Y, Tabata $\mathrm{T}$, et al. [Effects of peroxisome proliferator-activated receptor gamma ligands on monocrotaline-induced pulmonary hypertension in rats]. Nihon Kokyuki Gakkai Zasshi 2005;43(5):283-288. Article in Japanese.

333. Crossno JT Jr, Morris KG Jr, Klemm DJ. Attenuation of hypoxiainduced pulmonary artery remodeling by a peroxisome proliferatoractivated receptor-gamma agonist. Chest 2005;128(6 Suppl):580S.

334. Nisbet RE, Bland JM, Kleinhenz DJ, Mitchell PO, Walp ER, Sutliff $\mathrm{RL}$, et al. Rosiglitazone attenuates chronic hypoxia-induced pulmonary hypertension in a mouse model. Am J Respir Cell Mol Biol 2010;42(4):482-490.

335. Kim EK, Lee JH, Oh YM, Lee YS, Lee SD. Rosiglitazone attenuates hypoxia-induced pulmonary arterial hypertension in rats. Respirology 2010;15(4):659-668.

336. Yuan XJ, Wang J, Juhaszova M, Gaine SP, Rubin LJ. Attenuated $\mathrm{K}+$ channel gene transcription in primary pulmonary hypertension. Lancet 1998;351(9104):726-727.

337. Bonnet S, Rochefort G, Sutendra G, Archer SL, Haromy A, Webster $\mathrm{L}$, et al. The nuclear factor of activated $\mathrm{T}$ cells in pulmonary arterial hypertension can be therapeutically targeted. Proc Natl Acad Sci USA 2007;104(27):11418-11423.

338. Paulin R, Courboulin A, Meloche J, Mainguy V, Dumas de la Roque E, Saksouk N, et al. Signal transducers and activators of transcription-3/pim1 axis plays a critical role in the pathogenesis of human pulmonary arterial hypertension. Circulation 2011;123(11): 1205-1215.

339. Cowan KN, Heilbut A, Humpl T, Lam C, Ito S, Rabinovitch M. Complete reversal of fatal pulmonary hypertension in rats by a serine elastase inhibitor. Nat Med 2000;6(6):698-702.

340. Merklinger SL, Jones PL, Martinez EC, Rabinovitch M. Epidermal growth factor receptor blockade mediates smooth muscle cell apoptosis and improves survival in rats with pulmonary hypertension. Circulation 2005;112(3):423-431.

341. Stacpoole PW, Kerr DS, Barnes C, Bunch ST, Carney PR, Fennell EM, et al. Controlled clinical trial of dichloroacetate for treatment of congenital lactic acidosis in children. Pediatrics 2006;117(5): 1519-1531.

342. McMurtry MS, Bonnet S, Wu X, Dyck JR, Haromy A, Hashimoto $\mathrm{K}$, et al. Dichloroacetate prevents and reverses pulmonary hypertension by inducing pulmonary artery smooth muscle cell apoptosis. Circ Res 2004;95(8):830-840.

343. Michelakis ED, McMurtry MS, Wu XC, Dyck JR, Moudgil R, Hopkins TA, et al. Dichloroacetate, a metabolic modulator, prevents and reverses chronic hypoxic pulmonary hypertension in rats: role of increased expression and activity of voltage-gated potassium channels. Circulation 2002;105(2):244-250. 
344. Huddleston CB. Lung transplantation for pulmonary hypertension in children. Pediatr Crit Care Med 2010;11(2 Suppl):S53-S56.

345. Aurora P, Edwards LB, Kucheryavaya AY, Christie JD, Dobbels F, Kirk R, et al. The Registry of the International Society for Heart and Lung Transplantation: thirteenth official pediatric lung and heart-lung transplantation report, 2010. J Heart Lung Transplant 2010;29(10):1129-1141.
346. Clabby ML, Canter CE, Moller JH, Bridges ND. Hemodynamic data and survival in children with pulmonary hypertension. J Am Coll Cardiol 1997;30(2):554-560.

347. Stenmark KR, Meyrick B, Galie N, Mooi WJ, McMurtry IF. Animal models of pulmonary arterial hypertension: the hope for etiological discovery and pharmacological cure. Am J Physiol Lung Cell Mol Physiol 2009;297(6):L1013-L1032.

\section{Discussion}

Willson: It's like a poster for translational research: clinical care follows the biology, and it's very exciting. After Flolan [epoprostenol], what's next in the kids that you deal with, and how do you advance therapy in these kids if they don't respond at one level?

Fineman: We discuss that in the clinic all the time. Some of us are going with the approach that if they've got bad disease and are not responding, we go after all 3 cascades up front: prostanoid, NO-cGMP, and ET-1. So we'll add sildenafil or tadalafil to augment cGMP, and bosentan to block ET receptors. The issue with bosentan is that about $5 \%$ of the time the liverfunction test results become elevated and you have to stop it, so it requires blood draws once a month, which can be an important issue in a pediatric patient.

Unfortunately, there are no data to drive these decisions. Hopefully, future research will identify the relative roles of different pathobiologies in these patients, allowing us to tailor our choices based on the underlying pathobiology. It is becoming clear that although the end-stage anatomic changes may be similar between patients, the underlying pathobiology may be very different. This is clearly a spectrum of disease.

Branson: Is there ever a reason to have a patient on mechanical ventilation getting INO and aerosolized Flolan? I see it happening all the time, and it's an issue because the aerosolized Flolan fouls the sample line on the machine, making it difficult to use them both at the same time.
Fineman: I could see using both in a patient who is chronically ill on iloprost or inhaled prostacyclin and who gets critically ill. You may want to use INO in that ventilated patient and not stop their prostanoid therapy during that time. Without knowing if they respond particularly well to prostanoids versus INO, in general a good dose of INO is probably going to offset anything you can achieve with prostanoids in the acute setting.

Walsh: If we initiated INO without a positive response and then added Flolan and received a positive response, should we then consider stopping the INO?

Fineman: Yes. If it's a chronic problem and if they have a good response to INO as well, then you could argue to have them on sildenafil or tadalafil long-term, to augment that cascade. But if you saw no response to that cascade and you start getting a response with Flolan, then you could argue to just leave them on a prostanoid.

DiBlasi: At Seattle Children's Hospital we're conducting a study of inhaled iloprost and our ability to wean INO. However, it has been very difficult to enroll patients, because they are receiving HFOV [high-frequency oscillatory ventilation], and it is unclear if we can effectively deliver nebulized iloprost during HFOV. I have searched the literature and there are virtually no data on aerosol drug delivery with the available aerosol delivery devices during HFOV. Luckily, there are a few posters being presented at the AARC [American Association for Respiratory Care] Open Forum this year that might help answer that ques- tion. Do you have any evidence that administering this drug-not albuterol, but some of the vasoactive drugs you mentioned in your presentationare safe and effective during HFOV?

Fineman: No, I don't know of any studies that have looked at that. It's problematic.

Cheifetz: Jeff, that was probably the best review of PH I have seen. You presented numerous therapy options. If you use your crystal ball, with everything that is in the pipeline, how do you think chronic pulmonary hypertension will be most optimally managed in 5 years?

Fineman: We're learning a great deal about the pathobiology of $\mathrm{PH}$, and are beginning to appreciate the spectrum of possible pathobiologies. In particular patients, all the new therapies - the kinase inhibitors, the antiinflammatory agents, the PPAR gamma agonists, and the NOS couplers-can be beneficial. This has been demonstrated in isolated case reports. The problem is identifying which patients will benefit from which agents. I am concerned that we won't be able to answer any of these questions. $\mathrm{PH}$ is a rare disease, and it's really hard to study these patients. It will require a true collaborative multinational effort.

Willson: What about anticoagulation?

Fineman: Yes, we use it. Short of there being a known underlying thromboembolic disease, there probably are no great data on anti-coagulants. Whether you use aspirin or coumadin 
often depends on the child's age, activity level, family preference, et cetera. If they have a central line, you'd probably want to be more aggressive with anti-coagulation.
Cheifetz: When do you start anticoagulation? On the day of acute presentation, or later?

Fineman: Usually on presentation. However, if they have not been on anti-coagulation therapy and they now have low output, you may want to start therapy to minimize the risk of thrombus formation in the heart.

This article is approved for Continuing Respiratory Care Education credit. For information and to obtain your CRCE

(free to AARC members) visit www.RCJournal.com 